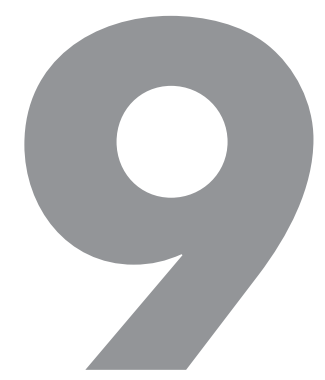

\title{
PRAZO PARA PROPOSITURA DA AÇÃO RESCISÓRIA
}

As opções de política legislativa se erguem sob os pilares do Estado Democrático de Direito (art. 5 XXXVI, da Constituição Federal de 1988)..$^{1}$ O prazo para propositura da ação rescisória é uma dessas opções, remontando à segurança jurídica das decisões judiciais.

A coisa soberanamente julgada, aquela em que não cabe mais falar-se nem mesmo em ação rescisória, ocorria, no sistema do Código Civil de 1916, em cinco anos. ${ }^{2}$

1 A propósito, hoje há um movimento crescente pela atuação direta do povo no exercício democrático, tomando espaço nas circunstâncias em que seus representantes não atuam com a devida representatividade. $\mathrm{Na}$ atualidade, "a democracia representativa desce, a democracia direta sobe. A observação pode servir para emoldurar a agitação social nos mais diferentes espaços do mundo: os protestos contra o sistema financeiro em plena Wall Street, em Nova York, contra o governo grego nas ruas de Atenas ou contra o presidente do Egito, na Praça Tahrir, no Cairo. Entre nós, explica o descrédito da sociedade na instituição política”. Por outro lado, mantém-se o crédito no Judiciário, que é uma das instituições mais representativas no Brasil. Isso se deve, em muito, por sua independência vista na prática, sem interferência dos demais Poderes. (TORQUATO, Gaudêncio. Democracias - uma sobe, outra desce. O Estado de S.Paulo, Caderno A, edição de 10.02.2013. p. 2).

2 “Art. 178. Prescreve: (...) $\$$ 10. Em 5 (cinco) anos: (...) VIII - O direito de propor ação rescisória." (Redação dada pelo Decreto do Poder Legislativo n. 3.725, de 15.01.1919) - Código Civil - Lei 
No sistema anterior (CPC/1973), a ação rescisória deveria ser proposta dentro do biênio ${ }^{3}$ decadencial previsto no art. 495. Tal prazo permaneceu o mesmo com a edição do Código de Processo Civil de 2015 (art. 975). Mas como se faz a contagem desse prazo? Quando ele tem início? E seu fim?

Admitida a singularidade ou pluralidade de decisões meritórias no mesmo processo, por exemplo, quando há antecipação de tutela em cognição exauriente (hipótese do art. 311 do CPC/2015), a resposta sofrerá ligeira diferenciação. Todavia, como se trata de prazo de natureza decadencial, sendo contínua a contagem (não se prorroga nem se interrompe), o que interessa é saber quando ele inicia, tendo em vista que o final do ajuizamento tempestivo será até um dia antes da data do segundo aniversário do início da contagem do prazo. Saliente-se, por oportuno, que, terminando o último dia do prazo "durante férias forenses, recesso, feriados ou em dia em que não haja expediente forense, fica ele automaticamente prorrogado para o primeiro dia útil imediatamente subsequente (art. 975, $\left.\mathbb{S} 1^{\circ}\right) " \cdot{ }^{4-5}$

Embora o art. 207 do CC/2002 prelecione que, "salvo disposição legal em contrário, não se aplicam à decadência as normas que impedem, suspendem ou interrompem a prescrição", não há incompatibilidade entre este dispositivo e o

n. 3.071, de $1^{\circ}$ de janeiro de 1916. No Projeto do novo CPC, na primeira versão, firmou-se o dies ad quem para a propositura da ação rescisória em até, no máximo, um ano do trânsito em julgado da decisão.

3 A Medida Provisória n. 1.658-12/98, até reedições anteriores à MP 1.798-5, de 02.06.1999, trazia a regra da dobra do prazo para rescisória intentada pela União, Estados, Distrito Federal, Municípios, autarquias e fundações, mas tal dispositivo foi suspenso na ADI 1.910-1/DF (DJ 27.02.2004. p. 19). Pode-se dizer que a exceção ainda em vigor é o prazo de 8 (oito) anos do art. $8^{\circ}$-C, da Lei n. 6.739/79, "para ajuizamento de ação rescisória relativa a processos que digam respeito à transferência de terras públicas rurais”. (BUENO, Cassio Scarpinella. Curso sistematizado de direito processual civil: recursos, processos e incidentes nos Tribunais. Sucedâneos recursais: técnicas de controle das decisões judiciais. 2. ed. São Paulo: Saraiva, 2010. v. 5. p. 408).

4 "O termo final do prazo para o ajuizamento da ação rescisória, embora decadencial, prorroga-se para o primeiro dia útil subsequente, se recair em dia de não funcionamento da secretaria do Juízo competente”. (STJ - REsp 1112864 MG 2009/0059035-4, Rel. Ministra Laurita Vaz, julgado em 19.11.2014, CE - Corte Especial, DJe 17.12.2014).

5 "É preciso não confundir a decadência, como figura de direito material, com a preclusão ou peremptoriedade, instituto de direito processual. Em ambos os casos há prazos fatais, mas na sistemática processual pátria, mesmo os prazos fatais ou peremptórios, como aqueles ligados à formação da coisa julgada, não correm nas férias.” (SHIMURA, Sérgio Seiji. Arresto cautelar. 3. ed. rev. e ampl. São Paulo: RT, 2005. p. 590). 
art. 975, $\mathbb{S} 1^{\circ}$, do CPC/2015. "Primeiro, porque o próprio art. 207 do Código Civil consigna a expressão ‘salvo disposição em contrário’ e, no caso, há disposição em contrário. Segundo, porque essa disposição do Código Civil que trata da ininterruptibilidade do prazo decadencial é de natureza material; enquanto o enunciado legal do CPC/2015 que trata da prorrogação do prazo decadencial de rescisória é de natureza processual, por tratar de algo que está entre os planos pré-processual e processual". ${ }^{6}$

Na prática, a contagem do prazo bienal (art. 975 do CPC/2015) é bastante simples. É importante destacar que o prazo para ação rescisória inicia-se automaticamente, sem necessidade de outro formalismo, sendo de fácil demonstração pela simples vista dos autos. ${ }^{7}$

A fluência do prazo tem início no dia subsequente ao trânsito em julgado. $\mathrm{O}$ termo inicial do prazo é contado imediatamente ao trânsito em julgado da última decisão ${ }^{8}$ proferida no processo (art. 975, caput, CPC/2015), ainda que não veicule a decisão rescindenda (de mérito) e que não esgotados os recursos - Súmula 514 do Supremo Tribunal Federal. ${ }^{9}$ Some-se a isso o fato de que a ação rescisória, invariavelmente, exige que seja instruída com a certidão do trânsito em julgado. ${ }^{10}$

6 AlViM, Angélica Arruda (coord.) [et al.]. Comentários ao Código de Processo Civil, p. 1124.

7 Nesse sentido, é o seguinte precedente: "a certidão de trânsito em julgado emitida pela secretaria desta Corte Superior, à fl. 149, certifica apenas a ocorrência do trânsito em julgado, e não a data em que teria se consumado. Ação rescisória extinta, com resolução de mérito". (STJ AR 3.738/SP, Rel. Ministra Laurita Vaz, $3^{\text {a }}$ Seção, julgado em 27.05.2009).

8 O Superior Tribunal de Justiça consolidou posicionamento no sentido de que "o termo inicial do prazo decadencial de dois anos para a propositura de ação rescisória é o dia seguinte ao do trânsito em julgado da última decisão proferida na causa”. (REsp 607.917/AL, $5^{\text {a }}$ Turma, Rel. Ministra Laurita Vaz, DJe 29.09.2008).

9 A Súmula 514 do STF foi aprovada em sessão realizada em 03.12.1969, arrazoada nos antigos arts. 284, I, e 798 do Código de Processo Civil de 1939 e na Lei de Introdução ao Código Civil Brasileiro (atual Lei de Introdução às Normas do Direito Brasileiro), de 1942. Muito embora esteja em vigor, não mantém a coerência com o sistema atual, uma vez que a expressão "recursos" pode levar o intérprete a entender a ação rescisória como um sucedâneo recursal, ou seja, não se deve abandonar o recurso para ingressar com ação rescisória. O texto sumular dispõe que "admite-se ação rescisória contra sentença transitada em julgado, ainda que contra ela não se tenham esgotado todos os recursos". (Súmula 514 do STF, aprovada em 03.12.1969, DJ 10.12.1969. p. 5932).

10 "O trânsito em julgado desta decisão deu-se no dia 28 de abril de 2005, conforme certidão acostada à fl. 215 dos autos. A ação rescisória foi ajuizada no dia 11 de abril de 2007, portanto, dentro do prazo de dois anos de que dispunha o autor para exercer a sua pretensão desconstitutiva do julgado. Rejeito, portanto, a preliminar." Este é o nosso destaque do voto condutor 
Logo, o autor que pretender a rescisão do julgado não poderá deixar transcorrer in albis esse mesmo prazo, sob pena de decadência.

Consequentemente, o prazo de dois anos para ajuizamento da ação rescisória se inicia do trânsito em julgado material da sentença, o que ocorre quando todas as questões forem resolvidas ou julgadas no processo, ou seja, quando não for cabível qualquer recurso do último pronunciamento judicial. ${ }^{11}$

em precedente do STJ. Segue, ainda, parte interessante da ementa, verbis: “(...) A Corte Especial firmou a posição de que o termo a quo do prazo decadencial de dois anos para a propositura de ação rescisória é o dia seguinte ao do trânsito em julgado da última decisão proferida na causa. 2. A Corte Especial editou o verbete da Súmula 401, segundo a qual: 'O prazo decadencial da ação rescisória só se inicia quando não for cabível qualquer recurso do último pronunciamento judicial'”. (STJ - AR 3.747/RS, Rel. Ministro Castro Meira, 1a Seção, julgado em 10.11.2010, DJe 22.11.2010).

11 Flávio Cheim Jorge analisa a Súmula 401 do STJ: “É de se notar que (...) não há possibilidade de fracionamento da sentença ou acórdão, capaz de ensejar o trânsito em julgado parcial. Significa dizer: ainda que exista mais de um capítulo, para efeito de fluência do prazo recursal, a sentença rescindenda será vista como um todo indivisível. Desta feita, somente a partir da preclusão temporal ocorrida no julgamento do último recurso é que começa a fluir o prazo de 2 anos para a ação rescisória. De outro lado, outra questão abordada pelos acórdãos que deram origem à Súmula 401 diz respeito ao efeito ex nunc do juízo de admissibilidade dos recursos. Como já tivemos oportunidade de abordar em outras oportunidades, a despeito da natureza declaratória da decisão que não conhece (admite) do recurso, o efeito dela decorrente será ex nunc. Isto é, o prazo para o ajuizamento da ação rescisória somente começa a fluir a partir do trânsito em julgado da última decisão proferida no processo, ainda que se discuta exclusivamente esse requisito de admissibilidade. A ratio essendi de tal entendimento reside basicamente em duas ordens: (i) a parte não pode ser prejudicada pela demora do Judiciário que deixa de decidir essa questão em prazo maior do que 2 anos; (ii) não se pode exigir da parte o ajuizamento de ação rescisória condicional. Aliado a esse entendimento, compreende-se que, sendo o recurso manifestamente inadmissível (intempestivamente flagrante ou falta de preparo), o efeito não deve ser ex nunc, mas sim ex tunc, sob pena de se privilegiar o recorrente desonesto que se utiliza de remédio recursal sabidamente inadmissível. Com efeito, quanto a essa última questão, impende ressaltar que em 4 julgados o STJ ratificou esse entendimento (REsp 639.233, Rel. Ministro José Delgado; Emb. Div. 441.252, Rel. Ministro Gilson Dipp; REsp 841.592, Rel. Ministro Luiz Fux; REsp 765.823, Rel. Ministro Herman Benjamim). Todavia, em um deles (REsp 543.368, Rel. Ministro Castro Meira), o STJ desconsiderou a manifesta intempestividade como causa apta a fazer fluir imediatamente o prazo para o ajuizamento da ação rescisória. O Relator entendeu que, mesmo sendo intempestivo o recurso, não se poderia exigir da parte o ajuizamento da rescisória, enquanto não houvesse a conclusão de todos os passos dados na tramitação do feito". (JORGE, Flávio Cheim. Análise da Súmula 401 do STJ. Disponível em: $<$ http://www.cjar.com.br>. Acesso em: 16 jul. 2011). 
Veja-se que poderá ocorrer o trânsito em julgado formal e o trânsito em julgado material em tempos distintos. Nas questões de mérito resolvidas por decisão interlocutória (por exemplo, com aplicação do art. 497 ou do art. 311, ambos do CPC/2015), a irrecorribilidade marcará o trânsito em julgado formal, todavia o trânsito em julgado material somente há de ocorrer do último julgado no processo (seja de mérito ou não). Esse reflexo na diferenciação do prazo entre o trânsito em julgado formal e o trânsito em julgado material não ocorre, por exemplo, quando for proferida apenas uma sentença final e definitiva no processo e não houver recurso. Nesse caso, ambos os trânsitos em julgado (formal e material) serão concomitantes.

Em resumo, o início da contagem do prazo decadencial (ou seja, o termo inicial do prazo para a propositura da ação rescisória) se conta, ao menos em tese: ${ }^{12}$

a) da publicação da decisão, tratando-se de:

a1) decisão de mérito originalmente irrecorrível, tendo em vista a concomitância da ocorrência do trânsito em julgado formal e material;

a2) última decisão no processo, portanto irrecorrível, seja de mérito ou não, tenha o recurso sido conhecido ou não (intempestividade, falta de preparo, ${ }^{13}$ dentre outros, desde que não haja condenação por litigância de má-fé na interposição do recurso);

a3) da data do requerimento de desistência do prazo recursal, validamente requerida, se em curso este prazo;

b) do dia seguinte ao termo ad quem do prazo recursal:

b1) tratando-se de decisão de mérito recorrível, mas que o recurso não tenha sido interposto;

b2) da penúltima decisão, seja de mérito ou não, muito embora recorrível e, de fato, tenha sido interposto o recurso e não conhecido, sendo que a fundamentação da motivação do não conhecimento atrelou-se à condenação por litigância de má-fé pela interposição do recurso.

12 COSTA, Carlos Coqueijo Torreão da. Ação rescisória. 2. ed. São Paulo: LTr, 1982. p. 130.

13 Não obstante a redação do art. 511 do CPC, segundo a qual o preparo deve ser comprovado no momento da interposição do recurso, há casos em que a parte comprova a impossibilidade da concomitância da juntada, e é admitida a juntada posterior. Há também casos em que se admite a juntada posterior; se interposto o recurso, o prazo final ainda não se escoou. Atente-se ainda que, nos Juizados Especiais Cíveis, é possível a efetivação do preparo em até 48 horas da interposição do recurso, conforme dispõe o art. 42, $\mathbb{S} 1^{\circ}$, da Lei n. 9.099/95: “O preparo será feito, independentemente de intimação, nas quarenta e oito horas seguintes à interposição, sob pena de deserção". Corresponde ao art. 511 do CPC/1973 o art. 1.007 do CPC/2015. 
A última decisão, em princípio, seja de mérito ou não, é a que marca o início do prazo para a ação rescisória. ${ }^{14-15}$ Não se admite o ajuizamento da ação rescisória condicional, que aguardasse o prazo se perfazer para seguir andamento, pois, proposta antes do prazo, resultará a extinção da ação por falta do pressuposto específico: o trânsito em julgado da decisão de mérito. ${ }^{16-19}$

Esclareça-se que o prazo para a propositura da ação rescisória pode ser contado já da data da publicação da decisão rescindenda (hipótese da alínea $a$, supra), quando: a) há renúncia das partes ao recurso, antes de iniciado o prazo para sua interposição; b) a parte autora for integralmente vencedora por ter o réu reconhecido a procedência do pedido (art. 487, III, alínea $a$, do CPC/2015). Poder-se-ia também aventar tal hipótese quando: c) interposto o último recurso cabível ao Supremo Tribunal Federal, esgotando-se os recursos cabíveis (tratar-se-á de

14 PORTO, Sérgio Gilberto. Comentários ao Código de Processo Civil. São Paulo: RT, 2000. v. 6. p. 397.

15 A matéria não é pacífica. Em sentido contrário, com referência às lições de José Carlos Barbosa Moreira, colaciona-se o seguinte aresto do Supremo Tribunal Federal: "o termo inicial de prazo de decadência para a propositura da ação rescisória coincide com a data do trânsito em julgado do título rescindendo. Recurso inadmissível não tem o efeito de empecer a preclusão". (STF AR 1.472/DF, Rel. Ministro Marco Aurélio, julgado em 07.12.2007).

16 CARNEIRO, Athos Gusmão. Ação rescisória, biênio decadencial e recurso parcial. Revista Forense, Rio de Janeiro, v. 93, abr./jun. 1997. p. 338.

17 "A ação rescisória em verdade é uma forma de ataque a uma sentença já transitada em julgado, daí a razão fundamental de não se poder considerá-la um recurso. Como toda ação, a rescisória forma uma nova relação processual diversa daquela onde fora prolatada a sentença ou o acórdão que se busca rescindir." (SILVA, Ovídio Baptista da. Curso de processo civil. Porto Alegre: Sergio Antônio Fabris, 1987. v. I. p. 409).

18 Pressuposto geral para o ajuizamento da ação rescisória, atendido o prazo decadencial bienal, é a existência de uma decisão, sentença ou acórdão, que haja transitado em julgado, isto é, alcançado a imutabilidade inerente à coisa julgada material: "se a sentença não é de mérito, a parte não tem interesse processual para rescindi-la porque pode renovar a demanda”. (GRECO FILHO, Vicente. Direito processual civil brasileiro. São Paulo: Saraiva, 1984. v. 2. p. 364). Importante ressaltar que, segundo o art. $966, \mathbb{S} 2^{\circ}$, do CPC/2015, a ação rescisória terá cabimento para as hipóteses em que, embora a decisão não analise o mérito, haja impossibilidade de a demanda ser reproposta ou o recurso interposto não ser conhecido, equivocadamente.

19 Há quem entende de modo diverso: "não se impede, contudo, o ajuizamento de ação rescisória contra a decisão proferida autonomamente, ao longo do processo, e que tenha transitado em julgado, embora o prazo ainda não tenha iniciado. Incide, também aqui, a regra geral prevista no $\mathbb{4} 4^{\circ}$, do art. 218 do CPC/2015 ('Será considerado tempestivo o ato praticado antes do termo inicial do prazo')”. (MEDINA, José Miguel Garcia. Novo Código de Processo Civil comentado, p. 1406). 
decisão irrecorrível), mas no atual sistema tal decisão não é de todo irrecorrível, pois sempre serão cabíveis os embargos declaratórios, ainda que com o fim de mero esclarecimento, com prazo de cinco dias para sua interposição, conforme o art. 1.023 do CPC/2015.

Em geral, o trânsito em julgado da decisão, para efeitos recursais, pode se dar em tempos distintos para as partes e para litisconsortes diversos, máxime quando há cumulação de ações e uma delas já se resolve ante a propositura de recurso parcial. Todavia, o trânsito em julgado material da sentença só ocorrerá com o último recurso julgado, atendendo ao princípio da unicidade da sentença.

Perceba-se que, em tese, de qualquer decisão são cabíveis embargos declaratórios, razão pela qual é defensável um plus na contagem do prazo para decisões ditas irrecorríveis. ${ }^{20}$

Se for sentença irrecorrível ou irrecorrida, o início do prazo para ação rescisória será contado individualmente ou haveria um marco de início do prazo para todas as decisões, seguindo o princípio da unidade da sentença. Passemos à análise deste e de outros pontos relevantes sobre o prazo da ação rescisória.

\subsection{AUSÊNCIA DA INTERPOSIÇÃO DE RECURSO}

Realmente não se exige o esgotamento dos recursos para o cabimento da ação rescisória (Súmula 514, STF). ${ }^{21}$

Assim, quando a parte dispuser de recurso e não manejá-lo, o início do prazo se dá no primeiro dia subsequente ao fim do prazo para a interposição do recurso que em tese seria cabível para impugnar a última decisão judicial; quando a parte não dispuser de mais nenhum recurso, subsistirão eventuais embargos de declaração (a ser interpostos em cinco dias), que, em tese, são cabíveis de qualquer decisão; a regra será a mesma, acrescendo-se os cinco dias derradeiros - art. 224 do CPC/2015 - como plus, na forma do já exposto no tópico anterior. ${ }^{22}$

Por fim, note-se que os vícios que autorizam a ação rescisória são tão graves que, em sua maioria, participam da categoria de matéria de ordem pública (por

\footnotetext{
20 “Em seu conceito moderno, o Direito é a arte do justo e do razoável.” (STJ - REsp 237.504/CE, Rel. Ministro Humberto Gomes de Barros, DJ 16.10.2000).

21 "Admite-se ação rescisória contra sentença transitada em julgado, ainda que contra ela não se tenham esgotado todos os recursos." (Súmula 514 - STF, 03.12.1969, DJ 10.12.1969, p. 5932; DJ 11.12.1969, p. 5948; DJ 12.12.1969, p. 5996).

22 Segundo o Enunciado n. 401 da Súmula deste Superior Tribunal de Justiça, “o prazo decadencial da ação rescisória só se inicia quando não for cabível qualquer recurso do último pronunciamento judicial".
} 
exemplo, incompetência, prova falsa, ofensa à coisa julgada, parcialidade do juiz etc.) e, nessas hipóteses, é cabível excepcionalmente o recurso derradeiro de embargos de declaração com efeitos infringentes do julgado originário, desde que dentro do quinquídio legal.

Assim, não se pode afastar, derradeiramente, no feito principal, ao menos nos casos em que se veicule na ação rescisória fundamento de matéria de ordem pública, o cabimento dos embargos de declaração e, consequentemente, caso não tenha sido utilizado, nos casos em que esgotados todos os recursos, frise-se, menos este, o sobreprazo de cinco dias.

\subsection{ERRO FORMAL NA CONTAGEM DO PRAZO}

Frise-se que a natureza do prazo de dois anos para a ação rescisória é decadencial para a propositura da ação (quanto a esta, não há suspensão, nem interrupção), uma vez que se relaciona com o exercício de um direito. Nessa linha, podem ocorrer, em casos pontuais, certidões lavradas com erro e recursos interpostos fora do prazo, dificultando tal contagem, exigindo especial conferência, não somente pela vista da certidão ou da decisão preferida no último recurso, mas pela eventual mácula na idoneidade destes para atestar a tempestividade. ${ }^{23}$

23 A contagem do prazo é muito técnica e suscita controvérsia. Veja a seguinte decisão: “a presente Rescisória não subsiste à análise de seus pressupostos de admissibilidade, especialmente no que pertine ao prazo para seu ajuizamento, conforme será adiante explanado. Inicialmente, cumpre ponderar que, de acordo com o artigo 485, caput, do Código de Processo Civil, a Ação Rescisória é cabível nas hipóteses elencadas em seus incisos e - vale ressaltar - sempre em face de decisões de mérito. Pois bem. Na presente hipótese, o trânsito em julgado da ação originária/ subjacente ocorreu em 16.12.2005 (fl. 144 verso). A Ação Rescisória, por sua vez, foi ajuizada em 05.06.2008. Nesse ponto, oportuno observar que, após o trânsito em julgado da ação originária, houve naquele feito interposição intempestiva de Recurso Especial por intermédio da parte autora. Em razão desse fato, o Recurso Especial não foi admitido conforme cópia da decisão da Vice-Presidência desta Corte acostada à fl. 494. Inconformada com esse decisum, ingressou a parte autora com o Agravo de Instrumento n. 2006.03.00.072000-8. Consultando o andamento processual de tal feito no site do Superior Tribunal de Justiça, observa-se ter sido ele autuado naquela Corte Superior sob o n. Ag 856306, o qual não foi conhecido naquela instância, ante sua intempestividade. A decisão em referência foi prolatada pelo Ministro Felix Fischer e transitou em julgado na data de 18.04.2007. Do acima relatado, verifico que a última decisão de mérito prolatada na ação subjacente foi a que, neste Tribunal, rejeitou os embargos de declaração interpostos pela parte autora (fls. 138/143), sendo que seu trânsito em julgado ocorreu, como mencionado acima, em 16.12.2005. Desta forma, exsurge cristalina a decadência na presente hipótese, ante o decurso de prazo superior a dois anos até o ajuizamento da 
Assim, do ponto de vista empírico, nem sempre é tão fácil a contagem do prazo bienal. Todavia, ainda que auxiliado por seu advogado, é do autor da ação rescisória o ônus exclusivo de efetuar a contagem do prazo decadencial, e não se admitirá atribuir ou transferir esse ônus ao integrante do Poder Judiciário, pois ao funcionário do respectivo cartório judicial apenas compete certificar o fato ocorrido, nunca realizar pronunciamento de direito material ou processual.

Mas, encerrando-se o prazo para ajuizamento da ação rescisória em dia não útil, sem expediente forense, após a edição do CPC de 2015, ele será automaticamente prorrogado para o primeiro dia útil subsequente (art. 975, $\mathbb{S} 1^{\circ}$ ). ${ }^{24}$ Para efeitos da citação e respectiva configuração da decadência, uma vez distribuída a ação dentro do biênio, o procedimento comporta a aplicação analógica do art. $240, \mathbb{S} 1^{\mathrm{o}}$, do $\mathrm{CPC} / 2015 .{ }^{25}$

\subsection{PRAZO EM TESE E IMPOSSIBILIDADE DE CONTAGEM DIFERENCIADA PARA CADA PARTE}

O transcurso do prazo será implacável, mesmo que seja ínfimo, posto que não se permite prorrogação do prazo decadencial para propositura da ação

Rescisória (artigo 495 do CPC). (...) Ante o exposto, indefiro a petição inicial e julgo extinto o processo, com resolução do mérito, nos termos do artigo 295, inciso IV, c/c o artigo 269 , inciso IV, e 495, todos do CPC. Prejudicado o pedido de tutela antecipada”. (TRF3 - Decisão Monocrática em Ação Rescisória 0020683-58.2008.4.03.0000/SP - AR 6.240, Relator Fausto de Sanctis, julgado em 25.04.2011, DJ 19.05.2011). Ressalte-se que, com a edição do novo CPC, as hipóteses de cabimento para a ação rescisória estão presentes no art. 966, e, nos termos do $\mathbb{2} 2^{\circ}$ do mesmo artigo, tal demanda poderá ser interposta contra decisões que não resolvem o mérito, mas impedem a propositura de demanda similar ou o conhecimento do recurso interposto.

${ }^{24}$ FLEXA, Alexandre; MACEDO, Daniel; BASTOS, Fabrício. Novo Código de Processo Civil: temas inéditos, mudanças e supressões. 2. ed. rev. ampl. e atual. Salvador: JusPodivm, 2016. p. 679 .

${ }_{25}$ Muito embora seja o presente estudo vinculado ao processo civil, vale verificar a aplicação na Justiça do Trabalho, conforme TST, Enunciado n. 100 “(...) IX - Prorroga-se até o primeiro dia útil, imediatamente subsequente, o prazo decadencial para ajuizamento de ação rescisória quando expira em férias forenses, feriados, finais de semana ou em dia em que não houver expediente forense. Aplicação do art. 775 da CLT. (ex-OJ n. 13 da SBDI-2 - inserida em 20.09.00); X - Conta-se o prazo decadencial da ação rescisória, após o decurso do prazo legal previsto para a interposição do recurso extraordinário, apenas quando esgotadas todas as vias recursais ordinárias”. (ex-OJ n. 145 da SBDI-2, DJ 10.11.2004). RA 63/1980, DJ 11.06.1980 - Nova Redação - Res. 109/2001, DJ 18.04.2001 - Incorporadas as Orientações Jurisprudenciais ns. 13, 16, 79, 102, 104, 122 e 145 da SBDI-2) - Res. 137/2005, DJ 22, 23 e 24.08.2005. 
rescisória ${ }^{26}$, salvo quando o último dia do prazo terminar "durante férias forenses, recesso, feriados ou em dia que não houver expediente forense", consoante a redação do art. $975, \mathbb{S} 1^{\circ}, \mathrm{CPC} / 2015$.

Assim, uma interpretação que opte por enrijecer o prazo poderá revelar-se injusta; por outro lado, uma interpretação demasiadamente elástica, sem se atentar para as particularidades do caso, será igualmente injusta. ${ }^{27}$

26 Essa lição já é antiga: "a contagem do prazo de decadência da ação rescisória começa a correr da data do trânsito em julgado da decisão”. (STF - RE 97.450, 1ª Turma, Rel. Ministro Soares Munhoz, julgado em 17.08.1982, DJ 03.09.1982).

${ }^{27}$ Há que se ter presente que as interpretações autênticas geram consequências. Não se pode esquecer que "a melhor interpretação da lei é a que se preocupa com a solução justa, não podendo o seu aplicador esquecer que o rigorismo na exegese dos textos legais pode levar a injustiças”. (STJ - REsp 299, 4 a Turma, Rel. Ministro Sálvio de Figueiredo, RSTJ 4/1554, DJU de 02.10.1989). No voto preliminar da lavra do Exmo. Sr. Ministro Humberto Gomes de Barros, nos Embargos de Divergência em REsp 404.777/DF, ficou assentado: pelo acolhimento do processamento da ação rescisória antes do julgamento da última decisão no processo: "é bom que decidamos esta questão com rapidez, à luz da lei processual brasileira, pois gera uma perplexidade brutal: imaginem V. Exas. o Banco Central propondo uma ação rescisória e imputando-lhe um valor alto, e, posteriormente, decide-se que essa rescisória é precipitada, não se conhecendo dela, extinguindo-se o processo e condenando-se a outra parte. Pedindo vênia à divergência, rejeito a preliminar”. No voto preliminar da lavra do Exmo. Sr. Ministro Francisco Peçanha Martins, nos Embargos de Divergência em referência, constou o seguinte: "inicialmente, quero dizer que, longe de defender o terrorismo ou de querer implantá-lo, estou preocupado, sim, é com o terrorismo que poderá resultar na morosidade da resposta às lides entre os cidadãos e na confusão que resulta de uma má interpretação, 'data venia'. (...) E no art. 467, define a coisa julgada nestes termos: 'Denomina-se coisa julgada material a eficácia, que torna imutável e indiscutível a sentença, não mais sujeita a recurso ordinário ou extraordinário.' Vale dizer: nos termos da lei processual e exatamente nos termos do artigo 495/CPC, que regula o prazo da rescisória ele só se inicia quando proferida a última decisão da causa, ou seja, quando a sentença se completa e extingue o processo, porque, se assim não for, seremos levados ao absurdo, ao qual o Ministro Franciulli Netto chamou a nossa atenção, qual seja: o de existir ação prosseguindo enquanto rescisórias estarão sendo propostas em juízo, ao longo do tempo e nas competências diversas. Ora, isso é um contrassenso, data maxima venia. Não há confundir ação rescisória com recurso, que impede o trânsito em julgado da sentença, protraindo, no tempo e no espaço, a extinção do processo. A impugnação parcial da sentença não conduz à extinção do processo. E só com o esgotamento de todos os recursos possíveis, indiscutível, pois, a sentença, extinto o processo, se constitui à 'coisa julgada material', como define o art. 467/ CPC”. (STJ - EREsp 404.777/DF, Corte Especial, Rel. para acórdão Ministro Francisco Peçanha Martins, DJ 11.04.2005). Correspondem aos arts. 467 e 495 do CPC/1973, respectivamente, os arts. 502 e 975 do CPC/2015. 
Portanto, trilhando uma solução única, verifica-se que o prazo para ajuizamento da ação rescisória obedece ao critério que outorgue igualdade às partes, um mesmo modo de contagem do prazo, sendo imune a eventuais benefícios de prazo recursal mais alargado pela qualidade da parte ou pela formação de litisconsórcio com diferentes procuradores, de escritórios advocatícios distintos, em processos físicos (v.g., arts. 180, 183 e 229 do CPC/2015).

Assim, o prazo bienal para ajuizamento da ação rescisória é contado em tese, sem se levar em conta tais particularidades. ${ }^{28}$ Por exemplo, quando se tratar de litisconsórcio unitário, uma vez que o recurso proposto por uma parte aproveita à outra igualmente sucumbente, o prazo para ajuizamento da ação rescisória somente se iniciará do trânsito em julgado formal da última decisão proferida no processo, quando coincidirá a formação do trânsito em julgado material. ${ }^{29}$

28 Entendimento conforme o aqui defendido foi esposado no aresto assim ementado: "O prazo de decadência para ingresso de ação rescisória conta-se a partir do trânsito em julgado da decisão rescindenda que ocorre com o término do prazo para interposição do último recurso, em tese, pela parte, sem se levar em consideração a situação peculiar de cada parte, isto é, se está em prazo simples ou em dobro para recorrer". E continua o voto condutor: "É que não se conta o prazo para o trânsito em julgado, levando-se em consideração a situação peculiar de cada parte (prazo simples ou em dobro para recorrer). A propósito, confira-se o decidido na AR 1.293 SP, $3^{a}$ Seção, Rel. Ministro Felix Fischer: 'A jurisprudência desta Corte é pacífica no sentido de que o prazo para se propor ação rescisória se inicia no dia do trânsito em julgado da decisão rescindenda, que ocorre com o término do prazo para interposição do último recurso, em tese, pela parte.' Nesse sentido: AR 480/DF, Rel. Ministro José Delgado, 1a Seção, DJU 04.08.1997, p. 34.640; REsp 62.353/RJ, Rel. Ministro Sálvio de Figueiredo Teixeira, 4ª Turma, RSTJ

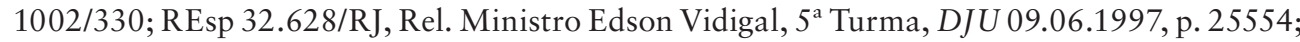
REsp 12.550/SP, Rel. Ministro César Asfor Rocha, 4ª Turma, DJU 04.11.1996, p. 42475; REsp

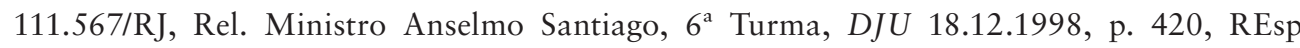
170.636/MG, Rel. Ministro Vicente Leal, 6 Turma, DJU 17.08.1998, p. 105”. (EDcl na AR 1275/SP, Rel. Ministro José Arnaldo da Fonseca, $3^{a}$ Seção, julgado em 12.09.2001, DJ 22.10.2001. p. 263).

29 Nesse sentido, vide a seguinte ementa: “Ação rescisória. Prazo decadencial. A propositura da ação rescisória no dia seguinte ao biênio, contado a partir do trânsito em julgado da decisão passível de rescisão, implica em reconhecimento da decadência, consoante dispõe o artigo 495 do Código de Processo Civil. Decadência reconhecida. Nem haveria se falar em violação a literal disposição de lei e erro de fato, pois foi dada interpretação razoável e adequada ao feito, bem como coerente apreciação do contexto probatório ação extinta com julgamento do mérito, à luz do inciso IV do artigo 269 do Código de Processo Civil”. Vejam-se alguns trechos do voto: o autor "pretende a rescisão do Acórdão proferido em 24.03.2009. Sobredito Acórdão transitou em julgado em 15.06.2009 para a então apelante. Não é o mesmo caso do que ocorreu com o [outro] réu [ora autor da ação rescisória]. É imprescindível observar que o autor deveria ter 
Nessa esteira, a distribuição diversa da sucumbência entre as partes pode interferir na decisão de recorrer ou não, mas essa realidade, em regra, não interferirá para diferenciar entre as partes a contagem do trânsito em julgado material para efeitos da propositura da ação rescisória, vale dizer, em princípio, não há prazo mais elástico para propositura da ação rescisória por uma das partes. $\mathrm{O}$ prazo em tese para o recurso da última decisão proferida no processo (por exemplo, embargos de declaração - cinco dias) vale para todos.

A única exceção é feita quanto ao litisconsórcio facultativo. Na lide finalizada e destacável das demais que prosseguem na instância recursal, sendo que um dos réus não prossegue no processo, haverá o trânsito em julgado material da decisão nessa relação processual em particular. Assim, em relação àquele que não tomou parte no recurso e também não recorreu, porque o prosseguimento do processo não lhe diz respeito, haverá o trânsito em julgado mais abreviado dessa sentença. Embora fisicamente reunidas as lides, trata-se de processos subjetivamente distintos, plenamente destacáveis um do outro. ${ }^{30} \mathrm{O}$ último recurso no

pleiteado a rescisão da sentença proferida em primeira instância em tempo oportuno, uma vez que a mesma transitou em julgado para ele há mais de dois anos: 'ocorre que o requerente não apelou da r. sentença de primeira instância, de tal forma que não se operou, em relação ao autor da presente ação, o efeito substitutivo previsto no art. 512 do CPC (...). Portanto, o requerente não poderia pleitear a rescisão do V. Acórdão que apreciou a apelação da corré. Deveria, sim, pleitear a rescisão da sentença condenatória de primeira instância (...). É importante destacar que, no caso presente, não há que se falar em litisconsórcio unitário, pois a responsabilidade pela prática de ato de improbidade administrativa é pessoal. Já se consumou, portanto, o prazo decadencial de dois anos para a propositura da rescisória, nos termos do art. 495 do CPC'. Dessa forma, para o autor desta Ação Rescisória, a irresignação remonta à sua condenação na sentença exarada pelo Juiz [a quo] aos 03.09.2008. Assim, de rigor o reconhecimento da decadência consoante dispõe o artigo 495 do Código de Processo Civil”. (TJSP - Decisão monocrática na Ação Rescisória 0098204-02.2011.8.26.0000, Rel. Des. Renato Nalini, Comarca: Assis, $1^{\circ}$ Grupo de Direito Público, julgamento em 26.06.2012, registro 06.07.2012). Correspondem aos arts. 269, 495 e 512 do CPC/1973, respectivamente, os arts. 487, 975 e 1.008 do CPC/2015.

30 Essa situação pode ocorrer em casos em que a pluralidade de autores se der de modo facultativo. Em verdade, no cotejo dos precedentes, verificam-se decisões, em princípio, contraditórias, mas que, numa análise mais apurada, convivem muito bem, pois são proferidas em bases fáticas diferentes. Assim, porquanto se possa defender que não é possível o trânsito em julgado parcial, no voto preliminar do Sr. Ministro Barros Monteiro, acompanhando o Relator, concluiu-se exatamente o contrário: "que a sentença é passível de transitar em capítulos. Isso decorre do próprio sistema do Código de Processo Civil nos seus artigos 505 e 512, na parte final. É a lição, aliás, do Sr. Ministro Luiz Fux, em sede doutrinária, no sentido de que, se a impugnação à sentença for parcial, forma-se coisa julgada sobre o que não fora objeto do recurso, iniciando-se, 
processo é que vale para contagem do prazo para ajuizamento da ação rescisória. Para aquele que tomou parte no recurso, ele pode ser autor da ação rescisória, contando-se o prazo desse recurso. Para aquele que foi excluído da lide, cumpriu a sentença, por exemplo, não tendo prosseguido na fase recursal, o trânsito em julgado material e a respectiva contagem do prazo para a ação rescisória se farão quando expirar o prazo do recurso em tese. ${ }^{31}$

Assim, há que se observar, na ação rescisória, que pode haver, excepcionalmente, contagem de prazo diferenciada entre as partes, tendo em vista o caso concreto e os aspectos recursais. Todavia, em regra, o trânsito em julgado material se realiza em momento único, do último julgamento que extingue definitivamente o processo. A exceção apontada, antes de ser excepcionalidade, acaba por confirmar a regra, pois a relação processual que prossegue é distinta da angularização formada na relação processual extinta.

\subsection{RECURSO NÃO CONHECIDO (NEGATIVA DE ADMISSIBILIDADE POR MANIFESTAMENTE INTEMPESTIVO, DESPROVIDO DE PREPARO OU INCABÍVEL) E FUNGIBILIDADE RECURSAL}

Como já dito, o prazo de dois anos para ajuizamento da ação rescisória se inicia do trânsito em julgado do último pronunciamento judicial (Súmula 401 STJ).

A ressalva normalmente feita refere-se aos recursos não conhecidos (quer por manifesta intempestividade, quer por falta de preparo no tempo oportuno, seja por manifesto não cabimento por interposição equívoca, um recurso por outro etc.).

portanto, o prazo para a propositura da ação rescisória quanto a essa parte”. (STJ - ERESP 404.777/DF, Corte Especial, Rel. para acórdão Ministro Francisco Peçanha Martins, DJ 11.04.2005). E, ainda, em acórdão da colenda Terceira Turma do STJ, Recurso Especial n. 267.451/SP, se diz igualmente o oposto, ou seja: “transita em julgado a decisão que permaneceu irrecorrida, pouco importando para efeito da contagem do prazo que tenha havido recurso sobre parte que não é objeto da ação rescisória, assim no caso sobre custas e honorários interposto pela ora ré". (STJ - REsp 267.451/SP, Rel. Ministro Carlos Alberto Menezes Direito, $3^{\mathrm{a}}$ Turma, julgado em 22.05.2001, DJ 20.08.2001. p. 462). Correspondem aos arts. 505 e 512 do CPC/1973, respectivamente, os arts. 1.002 e 1.008 do CPC/2015.

31 "O início dos prazos recursais pode variar, o que acontece quando as intimações aos litigantes não são feitas todas no mesmo dia; sendo diferentes os termos iniciais, obviamente também diferentes serão os dias em que o prazo termina e, se não houver recurso, o trânsito em julgado terá ocorrido em dias diferentes." (DINAMARCO, Cândido Rangel. Capítulos da sentença. São Paulo: Malheiros, 2002. p. 118). 
Nesses casos, são fortes os argumentos que apontam a razoabilidade em contar o prazo como se o último recurso não tivesse sido interposto. O recurso não conhecido seria um recurso inexistente para efeitos da contagem do prazo rescisório. Haveria um certo efeito retroativo da decisão que não conhece o recurso, retornando ao momento em que a decisão rescindenda foi proferida, e, por conseguinte, não valeria a tal última decisão para efeitos de contagem do prazo rescisório. ${ }^{32}$

No recurso não conhecido, a decisão que assim conclui teria efeitos ex tunc para contagem do trânsito em julgado. ${ }^{33}$ Não poderia ser excepcionada a natureza declaratória do juízo de admissibilidade. O recurso não conhecido não interferiria na contagem do prazo bienal para interposição da ação rescisória, ${ }^{34}$ pois a decisão rescindenda, na falta de outro recurso conhecido, terá transitado em julgado. ${ }^{35}$

32 Em sentido contrário, confira-se: "A despeito das alegações da recorrente de que se opera a decadência do direito de ajuizar a ação rescisória após o transcurso do prazo bienal, a ser contado da última decisão que tenha examinado o mérito, desconsiderando-se os recursos inadequados ou intempestivos, esta Corte Superior entende que, 'nos termos do art. 495 do CPC, o prazo para ajuizamento da ação rescisória somente tem início com o trânsito em julgado material, ou seja, após o transcurso in albis do prazo para recorrer, mesmo que o último recurso interposto não tenha sido conhecido por inobservância de requisito legal' (REsp 1.003.403/ MG, $5^{\text {a }}$ Turma, Rel. Ministro Arnaldo Esteves Lima, DJe 03.08.2009). Agravo regimental desprovido”. (STJ - AgRg no REsp 1.101.659/MG, Rel. Ministro Denise Arruda, 1a Turma, DJe 27.11.2009). Corresponde ao art. 495 do CPC/1973 o art. 975 do CPC/2015.

33 Conforme lição: "se da decisão que não tomou conhecimento do recurso cabia recurso e não foi interposto no prazo, houve trânsito em julgado. Se o foi, há outro julgamento: ou de não se conhece, e a sentença passou em julgado, ou dele se conhece, e a sentença rescindenda tem de ser a que foi dada em confirmação, ou a que consta do último julgamento". (PONTES DE MIRANDA, Francisco Cavalcanti. Tratado da ação rescisória, das sentenças e de outras decisões. Atualizado por Vilson Rodrigues Alves. 1. ed. Campinas: Bookseller, 1998. p. 368).

34 "O prazo decadencial estabelecido pelo art. 495 do CPC corre do trânsito em julgado da decisão que se queira rescindir, sendo meramente declaratório - e apto a produzir efeitos ex tunc - o juízo de admissibilidade dos recursos. Nem se diga que seria impossível, já nesse momento, o ajuizamento da ação rescisória se ainda pendente de julgamento algum recurso. Nada há a impedir a propositura da 'ação rescisória condicional'. Trago, aqui, à colação, o disposto no art. 811 do Código de Procedimento Civil chileno para reforçar o que sustento.” (CÂMARA, Alexandre Freitas. Ação rescisória. 2. ed. São Paulo: Atlas, 2012. p. 168). Corresponde ao art. 495 do CPC/1973 o art. 975 do CPC/2015.

35 Também no sentido de ocorrer o trânsito em julgado na origem, vide a doutrina de Nelson Nery Jr. (NERY JÚNIOR, Nelson; NERY, Rosa Maria de Andrade. Código de Processo Civil comentado e legislação extravagante, 9. ed., 2006, p. 699). 
Data venia, essa não é a posição que defendemos. A decisão que nega a admissibilidade ao recurso tem natureza constitutiva e, neste caso, é uma exceção e faz operar efeitos ex nunc ${ }^{36}$ para contagem do prazo rescisório. Afinal, seja ou não de mérito, é da última decisão que se conta o prazo rescisório (Súmula 401 STJ). ${ }^{37}$

Assim, o fato de ser o recurso interposto fora do prazo, sem o devido preparo ou em hipótese em que seja manifestamente incabível, ainda que ciente a parte previamente de que não será conhecido o recurso interposto, em nada mudará a realidade das coisas; o prazo para a ação rescisória continuará sendo contado da última decisão (no caso, aquela proferida no recurso não conhecido). ${ }^{38}$ Basta que não haja uma evidente má-fé do autor da ação rescisória. ${ }^{39}$

36 "Um segundo olhar acerca da mesma questão, ficando-se basicamente na segurança jurídica, vislumbra que, enquanto o juiz não se pronunciar acerca da (in)existência de determinado requisito de admissibilidade e, sobretudo, enquanto tal negativa não transitar em julgado, não se poderia falar, efetivamente, na certeza quanto ao não conhecimento recursal, independente de qual requisito se estivesse falando. Assim, esse pronunciamento que impede a análise do mérito recursal apresentaria eficácia ex nunc, somente produzindo efeitos a partir de sua prolação e, mais que isso, de seu trânsito em julgado." (FARIA, Márcio Carvalho. Considerações sobre o prazo rescisório no Novo CPC. In: DIDIER JR., Fredie (coord.); MACÊDO, Lucas Buril; PEIXOTO, Ravi; FREIRE, Alexandre. Novo CPC - doutrina selecionada, v. 6: processo nos tribunais e meios de impugnação às decisões judiciais. Salvador: JusPodivm, 2016. p. 209).

37 "Assim, o prazo para ajuizamento da ação rescisória tem início com o trânsito em julgado da última decisão proferida no processo, ainda que esta não tenha admitido o recurso (cf. STJ,

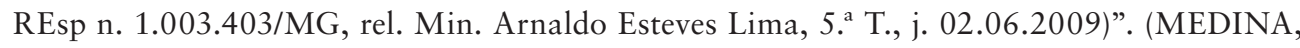
José Miguel Garcia. Novo Código de Processo Civil comentado, p. 1407).

38 "Essa é a posição que tem sido adotada pelo STJ, especialmente a partir do julgamento dos Embargos de Divergência em Recurso Especial n. 441. 252/CE, ocorrido em 29 de junho de 2005 (publicação em 18 de dezembro de 2006), realizado pela Corte Especial daquele Tribunal Superior. Na oportunidade, o colegiado, por maioria, tomando como suporte o voto do Min. Gilson Dipp, entendeu que 'existindo controvérsia acerca deste requisito de admissibilidade, não há que se falar no trânsito em julgado da sentença rescindenda até que o último órgão jurisdicional se manifeste sobre o derradeiro recurso"”. (FARIA, Márcio Carvalho. Considerações sobre o prazo rescisório no Novo CPC. In: DIDIER JR., Fredie (coord.); MACÊDO, Lucas Buril; PEIXOTO, Ravi; FREIRE, Alexandre. Novo CPC - doutrina selecionada, v. 6: processo nos tribunais e meios de impugnação às decisões judiciais, p. 211).

39 São remansosos os precedentes nesse sentido. Veja-se a seguinte ementa: "O prazo de decadência da rescisória começa a fluir a partir do trânsito em julgado do acórdão que julga intempestiva a apelação, salvo se demonstrado o comportamento malicioso do apelante, que age de má-fé para reabrir prazo recursal já vencido. Não demonstrada essa situação, o razoável é considerar que o recorrente confiava na eficácia do seu recurso, contando apenas do seu 
Essa conclusão está em consonância com o sistema processual e material, haja vista que a regra é que a ação rescisória não tenha nenhum efeito na execução do julgado rescindendo ( $1^{\mathrm{a}}$ parte do art. 969 do CPC/2015). Em condições de normalidade, a ação rescisória somente produzirá efeitos diante da excepcional procedência.

julgamento o prazo para a ação de rescisão. Entendimento diverso obrigará as partes a ingressarem com o recurso e com a ação rescisória, pois ninguém sabe de antemão qual será o julgamento sobre a admissibilidade. Anulação do acórdão que não fundamentou o deferimento de indenização em valores muito acima dos concedidos para a mesma situação. Recurso conhecido em parte, pela divergência, mas desprovido”. (STJ - REsp 441.252/CE, Rel. Ministro Ruy Rosado de Aguiar, $4^{a}$ Turma, julgado em 22.10.2002, DJ 17.02.2003 p. 289). Cite-se outro julgado, após o voto condutor que constou: "Discute-se no presente Recurso Especial o termo inicial de contagem do prazo decadencial para a propositura da Ação Rescisória. O acórdão rescindendo foi publicado em 24 de abril de 2000. Foram opostos Embargos de Declaração em 4 de maio de 2000, a que se negou seguimento por intempestividade, decisão esta publicada em 5 de junho de 2000 (f. 175). Foram interpostos Recurso Especial e Extraordinário contra a decisão que negou seguimento aos Embargos de Declaração, cujo seguimento foi também impedido por decisão publicada em 24 de novembro de 2000 (fl. 176). Esta Corte não conheceu o Agravo de Instrumento interposto contra a denegatória de seguimento do Recurso Especial, por decisão publicada em 6 de setembro de 2001 (fl. 176), que transitou em julgado conforme certidão à fl. 74. O dia 06.09.01 foi uma quinta-feira, ocorrendo o trânsito em julgado da decisão após o prazo do recurso cabível (5 dias, conforme art. 258, do RI/STJ). Assim, o trânsito em julgado da decisão desta Corte ocorreu em 14.09.01 (considerando que o dia 06.09.01 foi uma quinta-feira e o dia seguinte é feriado nacional). Finalmente, a Ação Rescisória foi ajuizada em 15 de setembro de 2003 (o dia 14.09.01 foi domingo). Esta Corte vem firmando o entendimento de que o prazo decadencial de 2 anos, para o ajuizamento da Ação Rescisória, tem início na data em que se deu o trânsito em julgado da última decisão, mesmo que nela se tenha discutido questão meramente processual relacionada à tempestividade dos Embargos de Declaração. No caso destes autos, não está evidenciada má-fé na oposição dos Embargos de Declaração em 4 de maio de 2000 (dez dias após a publicação do acórdão embargado), com intuito de ampliar o prazo para ajuizamento da Ação Rescisória”. O decisum recebeu a seguinte ementa: "Processual Civil. Ação Rescisória. Decadência. Termo Inicial. 1. O prazo decadencial de dois anos para o ajuizamento da Ação Rescisória tem início a partir do trânsito em julgado da última decisão no processo correspondente, ainda que ela se refira à intempestividade dos Embargos de Declaração. Precedentes (EREsp 441.252/CE, Rel. Ministro Gilson Dipp, Corte Especial, DJ 18.12.2006, REsp 543.368/RJ, Rel. Ministra Eliana Calmon, Rel. p/ Acórdão Ministro Castro Meira, Segunda Turma, DJ 02.06.2006). 2. Ressalva-se a hipótese de evidente má-fé na oposição dos Embargos, o que não se verifica no caso. Precedente (REsp 544.870/RS, Rel. Ministro Teori Albino Zavascki, Primeira Turma, DJ 06.12.2004). 3. Recurso Especial provido". (STJ - REsp 765.823/PR, Rel. Ministro Herman Benjamin, $2^{\text {a }}$ Turma, julgado em 27.03.2007, DJ 10.09.2007. p. 212). 
É lógico que esse entendimento deve ser aplicado à luz dos princípios da proporcionalidade e da razoabilidade. Não estamos a defender que um recurso interposto meses após o prazo, por exemplo, em não havendo nenhuma divergência sobre a contagem do prazo, poderia ensejar a tempestividade futura de uma ação rescisória. $\mathrm{Na}$ espécie, em especial nos casos em que a parte recorrente infratora for condenada na multa e/ou indenização processual - v.g., arts. 80, c/c 81, caput e $\mathbb{S} S 1^{\circ}, 2^{\circ}$ e $3^{\circ}$, do CPC/2015 - por má-fé reconhecida no motivo que ensejar o não conhecimento do recurso, não se poderá adotar esse entendimento mais garantista. Exclui-se essa aplicação. ${ }^{40}$

Entrementes, atendida a proporcionalidade e razoabilidade no recurso, embora não conhecido, mormente quando há discussão (no processo e amparada nas fontes do direito processual) sobre o motivo que ensejou a sua não admissão, é presumida a boa-fé da parte recorrente, razão pela qual o julgamento de um recurso não conhecido, até mesmo por intempestividade, poderá ensejar a contagem do dies a quo para ação rescisória, pois a melhor técnica processual repugna a surpresa como modo de afastar o direito ao acesso à justiça. ${ }^{41}$

E mais, ainda que não seja razoável, até mesmo o erro grosseiro ${ }^{42}$ se mostra legítimo a ensejar a contagem do prazo bienal rescisório da decisão de inadmissão

40 “Tal orientação tem sido excepcionada, contudo, nos casos em que o recurso não tenha sido conhecido em razão de intempestividade flagrante, e configurado erro grosseiro ou má-fé (cf. STJ, REsp 1.186.694/DF, rel. Min. Luiz Fux, 1. ${ }^{a}$ T., j. 03.08.2010)”. (MEDINA, José Miguel Garcia. Novo Código de Processo Civil comentado, p. 1407).

${ }^{41}$ Apresentando fundamentos contrários, vale a leitura da doutrina que conclui nesse mesmo sentido: "Mas já se decidiu que o prazo entre o trânsito em julgado teórico e o trânsito em julgado do último acórdão não deve ser computado, se o último recurso foi intempestivamente interposto. São reconhecidos os inconvenientes práticos de se desconsiderar o prazo de um recurso pendente que de futuro será inadmitido. As partes não sabem, muitas vezes, se o recurso não será conhecido, há situações práticas de dúvida, e, neste caso, para evitar surpresas, teria que propor a ação rescisória, suspendê-la, aguardando o julgamento do recurso. Diante desses inconvenientes práticos, o STF, contra a doutrina de José Carlos Barbosa Moreira e Pontes de Miranda, tem entendido, as mais das vezes, que a contagem se dá a partir do trânsito em julgado da última decisão, ainda que essa decisão tenha sido provocada por um recurso não conhecido por intempestividade ou por outro vício formal de qualquer ordem”. (RIZZI, Luiz Sérgio de Souza. Da ação rescisória. Revista de Processo, v. 26, p. 194).

42 A má-fé ou boa-fé não toca o conceito de erro grosseiro, pois apenas será causa de agravamento ou não do erro que, neste caso, poderá vir qualificado com a malícia. (FAGUNDES, Seabra. Dos recursos ordinários em matéria civil. Rio de Janeiro: Forense, 1946. p. 160; no mesmo sentido: LIMA, Alcides de Mendonça. Sistema de normas gerais dos recursos cíveis. São Paulo: Freitas Bastos, 1963. p. 219). 
do recurso; basta que não tenha sido reconhecida a má-fé na interposição do recurso.

Por óbvio, não estamos aqui a falar da hipótese de fungibilidade, pois, se acolhida a tese da validade e eficácia de um recurso interposto por outro, o recurso será normalmente conhecido, admitido.

Nesse passo, por exemplo, no julgamento de uma exceção de pré-executividade acolhida totalmente, com extinção da execução, restaria ao sucumbente interpor apelação. $\mathrm{Na}$ interposição de agravo de instrumento, quando seria o caso de apelação, não se poderá falar em "dúvida objetiva” nem em "inexistência de erro grosseiro". Assim, não comporta a aplicação do princípio da instrumentalidade das formas para assegurar o processamento pela fungibilidade recursal. Do acórdão em agravo de instrumento, resultaria invariavelmente, nessa hipótese, o não conhecimento. ${ }^{43}$ Ainda assim, como se trata de decisão de mérito, caberá a ação rescisória com o prazo contado do trânsito em julgado dessa última decisão, a decisão de inadmissibilidade do recurso. É engano, nessa hipótese, pensar no descabimento da ação rescisória, porque não se pode dar por expirado o prazo entre a decisão recorrida e a data de julgamento do agravo de instrumento, se não houve, na própria decisão de inadmissão, reconhecimento de má-fé da parte ou de seu patrono. Mostra-se razoável o cabimento da ação rescisória.

Esse desiderato não ocorre quando parte entrar com recurso que sabe que não será conhecido, sobrevindo concomitante condenação em litigância de má-fé.

Portanto, excepcionada a hipótese de condenação da parte recorrente em litigância de má-fé, pois o direito processual não tolera a má-fé na espécie, ${ }^{44}$ de ordinário, abre-se o cabimento da ação rescisória a partir do esgotamento dos recursos contra a última decisão no processo, seja ou não de mérito, seja ou não conhecido esse último recurso, ainda que o erro na interposição deste seja grosseiro, desde que presente ao menos um dos vícios de rescindibilidade. ${ }^{45}$

43 Sobre a vedação da fungibilidade, vide a seguinte ementa: "A decisão que acolhe exceção de pré-executividade põe fim à execução, por isso o recurso cabível para impugná-la é a apelação, e não o agravo de instrumento, sendo ainda inaplicável o princípio da fungibilidade recursal. Entretanto, se a execução fiscal prossegue porque houve a exclusão apenas de uma das partes, o recurso cabível é o agravo de instrumento”. (REsp 889.082/RS, Rel. Ministra Eliana Calmon, julgado em 03.06.2008).

${ }^{44}$ QUARCH, Tilman. Equilíbrio entre efetividade da tutela jurisdicional e eficácia do funcionamento judiciário: filtros recursais no direito processual civil alemão, com enfoque na Revision. Revista de Processo, São Paulo: RT, v. 37, n. 207, p. 85-132, maio 2012. p. 90.

45 "A partir do trânsito em julgado da decisão final, inicia-se a contagem do prazo para o ajuizamento da ação rescisória. Ora, a coisa julgada material opera-se quando a decisão não está mais 


\subsection{CAPÍTULOS DA SENTENÇA}

Referente ao prazo rescisório, há interessante indagação sobre os capítulos da sentença na pluralidade de pedidos, quando a execução é permitida sobre parcela deles (ou quanto a um deles), eis que já resolvidos e desprovidos de recursos ou irrecorridos, prosseguindo-se o feito de conhecimento apenas quanto a outro(s) pedido(s). ${ }^{46}$

Conquanto se possa pensar que uma causa de pedir dê ensejo à sentença que retrate várias questões que necessariamente serão solucionadas em capítulos distintos da decisão, via de regra, as decisões por capítulos, proferidas em tempos e atos distintos, não interferem na contagem do prazo da ação rescisória. Cada capítulo corresponde a uma decisão: haverá uma coisa julgada formal (isto é, preclusão $)^{47}$ para cada decisão, desde que se esgotem as possibilidades de impugnação ou que não ocorra a impugnação recursal pontual de cada uma

sujeita a qualquer recurso (CPC, art. 467 (...) e na dicção do $\mathbb{S} 3^{\circ}$ do art. $6^{\circ}$ da LINDB). (...) A data do trânsito em julgado corresponde à data do trânsito em julgado da última decisão. Com efeito, o prazo previsto no art. 495 do CPC somente flui quando é possível à parte ajuizar a ação rescisória. No particular, incide o princípio da utilidade, segundo o qual nenhum prazo pode ter curso quando é impossível sua utilização [não se aceita ação rescisória condicional]. Assim, interposto um recurso, enquanto este não vier a ser apreciado, não se pode ajuizar ação rescisória. Se o recurso vier a ser inadmitido, é a partir do trânsito em julgado da decisão que não o admitir que se inicia o prazo para a propositura da ação rescisória.” (DIDIER JR., Fredie; CUNHA, Leonardo José Carneiro. Curso de direito processual civil. Meios de impugnação às decisões judiciais e processo nos tribunais. 10. ed. rev., ampl. e atual. Salvador: JusPodivm, 2012. v. 3. p. 403). Correspondem aos arts. 467 e 495 do CPC/1973, respectivamente, os arts. 502 e 975 do CPC/2015.

46 "É muito difícil conceber uma sentença sem mais de um capítulo [parte, parcela, segmento], porque quase sempre algo há a ser decidido também quanto ao reembolso de despesas ou aos honorários da sucumbência (ainda que para negá-los); mas em uma decisão interlocutória essa unicidade é plenamente configurável (negar uma medida urgente, e nada mais).” (DINAMARCO, Cândido Rangel. Capitulos de sentença. 3. ed. São Paulo: Malheiros, 2008. p. 35).

47 Com sustentação em Chiovenda, podemos imaginar a proximidade da coisa julgada formal e da preclusão. Asseverar que, em certo caso, ocorreu a preclusão de uma questão, isto é, que os sujeitos do processo não poderão mais discuti-la no mesmo processo, e afirmar que no caso ocorrera a coisa julgada formal, com relação à mesma questão, via de consequência, será simples tautologia, modos de dizer a mesma coisa. A preclusão antes da sentença fixa o momento do qual não se permitirá inovar no processo, vedando-se a introdução de elementos cognitivos, pedidos ou defesas. Após a sentença, fixa o momento do qual não se permitirá mais nenhuma impugnação do decisório dentro do processo. A coisa julgada material se dá pela soma de todas as preclusões após a sentença de primeiro grau. Assim, a coisa julgada formal (preclusão) é pressuposto da coisa julgada material. Vide, com proveito, a doutrina: BARBI, Celso Agrícola. Da preclusão no processo civil. Revista Forense, Rio de Janeiro: Forense, v. 158, 1955. p. 65. 
delas. Todavia, a coisa julgada material somente se formará no conjunto. Apenas a soma ou reunião dos respectivos dispositivos das decisões de mérito definitivas transitarão materialmente em julgado e comporão, ao final, a sentença lato sensu, aquela que poderá ser objeto da ação rescisória.

Para melhor se entender uma sentença por capítulo, passemos "a exemplificar. Um capítulo vai resolver as questões preliminares que tinham sido suscitadas e, se não houver recurso, essas preliminares transitarão em julgado. Outro poderá apreciar as condições de ação e, se não houver recurso, esse capítulo transitará em julgado. $\mathrm{O}$ terceiro capítulo poderá cuidar das preliminares de mérito e, se não houver recurso, também transitará em julgado. O quarto poderá cuidar das questões prejudiciais e, se não houver recurso, transitará em julgado. Por fim, um quinto capítulo poderá cuidar do pedido ou dos pedidos" ${ }^{48}$ em subcapítulos.

E, como os capítulos da sentença sujeitam-se aos recursos - art. 1.002 do CPC/2015 -, diante da possibilidade total ou parcial do acolhimento de pretensões e das respectivas impugnações decisórias, pode um capítulo ser resolvido por decisão definitiva em tempos distintos.

Assim, nesse mesmo exemplo, suponha-se que o autor tenha formulado quatro pedidos. "Em relação a um deles, a sentença de primeiro grau, que afastou todas as preliminares invocadas pelo réu e indeferiu todos os pedidos formulados, permanece inatacada. Ao apreciar os outros três pedidos, a Corte de apelação, dois anos e meio após a publicação da sentença, dá parcial provimento ao recurso do autor para conceder um dos pedidos e negar os outros dois e, de ofício, reafirmar a sentença quanto às preliminares. Regularmente prequestionada a matéria, o autor interpôs recurso especial apenas quanto a um desses pedidos. $O$ réu, por seu turno, também interpôs recurso especial, ao fundamento de que o processo deveria ser extinto sem julgamento de mérito, diante da sua ilegitimidade para figurar no polo passivo, expressamente examinada pelo Tribunal de origem. $\mathrm{O}$ STJ, então, três anos após a interposição do recurso, dá provimento ao recurso do réu para anular o processo e julga prejudicado o recurso do autor." ${ }^{\text {49 }}$

Nesse caso, ao se admitir que o pedido irrecorrido teria materialmente transitado em julgado, ao entendimento de que cada capítulo da sentença seria visto separadamente, não haveria óbice ao ajuizamento da ação rescisória em até dois anos da decisão de primeira instância, muito embora a ação estivesse em curso para os demais pedidos.

48 Voto preliminar da lavra do Sr. Ministro José Delgado, do STJ, nos Embargos de Divergência em REsp 404.777/DF (2003/0125495-8), DJU 11.04.2005.

49 Voto preliminar da lavra do Sr. Ministro Franciulli Netto, do STJ, nos Embargos de Divergência em REsp 404.777/DF (2003/0125495-8), DJU 11.04.2005. 
Ora, a despeito de a parte não interpor o recurso e ajuizar a ação rescisória, infringindo a vedação de sua utilização como sucedâneo recursal, ${ }^{50-51}$ eventual procedência da ação rescisória (nessa forma incidental) com entrega do bem tutelado antes do julgamento final da ação originária poderia resultar no absurdo de que, ao final, confirmando o STJ a competência do órgão prolator da sentença, interferiria na ação como um todo, produzindo a situação absurda de que uma decisão no processo original possa causar a perda da eficácia da sentença produzida na ação rescisória. Por exemplo, como decorrência da aplicação do efeito translativo a um recurso acolhido para impugnação de outro capítulo da decisão meritória, mas que o conhecimento da matéria ex officio acabe por prejudicar o julgamento da ação rescisória. Ou pior, como o recurso ainda estava em andamento, julgada procedente a ação rescisória, haveria a declaração da competência do juízo, e, assim, tal julgamento poderia ser motivo de acionamento do Tribunal para que julgasse prejudicado o recurso interposto ou para que acolhesse, como rescindido, o capítulo recorrido, muito embora não tenha sido objeto da ação rescisória.

Em conclusão, deve-se ver que o absurdo não deve ser tolerado no direito. ${ }^{52-53}$ A ação rescisória é processo formulado sobre outro processo, na tentativa de

50 Não cabe ação rescisória como sucedâneo recursal. Vide ementa: "Constatada a utilização da ação rescisória pelo autor como sucedâneo recursal, na medida em que deixou de recorrer da decisão que julgou a ação de liquidação, bem como inocorrente a apontada ofensa a coisa julgada, impõe-se o indeferimento da inicial da ação rescisória, diante da falta de quaisquer das hipóteses elencadas no artigo 485 do Código de Processo Civil”. (TJRS - AR 70038614962/RS, $11^{a}$ Câmara Cível, Relator Antônio Maria Rodrigues de Freitas Iserhard, julgamento em 04.04.2012, DJ 04.05.2012).

51 O recurso não pode ser confundido com a ação rescisória e vice-versa. Não se "confunde com o recurso, justamente por atacar uma decisão já sob o efeito da res judicata, ou seja, depois da extinção do processo. (...) O recurso visa evitar ou minimizar o risco de injustiça do julgamento único. Esgotada a possibilidade de impugnação recursal, a coisa julgada entra em cena para garantir a estabilidade das relações jurídicas, muito embora possa correr o risco de acobertar alguma injustiça latente no julgamento. Surge, por último, a ação rescisória como remédio extremo, que colima reparar a injustiça da sentença trânsita em julgado, quando o grau de imperfeição é de tal grandeza que sugere a necessidade de (afastar a) segurança tutelada pela res iudicata". (THEODORO JÚNIOR, Humberto. Sentença - Direito processual civil ao vivo. 2. ed. Rio de Janeiro: Aide, 1997. p. 36).

52 Assim é a lição atribuída a Rui Barbosa: “ordenar o que não há meio de fazer, proibir o que se não pode evitar, é desarrazoar, é ensandecer. Não há de supor que a lei ordinária, quanto mais a lei constitucional, caduque e delire. Da interpretação dos textos legislativos se deve refugar sempre o absurdo". (MENDES NETO, João. Rui Barbosa e a lógica jurídica: ensaio de prática da argumentação. 2. ed. São Paulo: Saraiva, 1949. p. 132).

53 O principal objetivo do processo é a pacificação dos conflitos. Vide a doutrina: DINAMARCO, Cândido Rangel. Instituições de direito processual civil. São Paulo: Malheiros, 2001. v. II. p. 34. 
harmonizar ${ }^{54}$ a justiça e a segurança jurídica no caso julgado, em cuja sentença operou-se a coisa julgada material - sem esta não haverá ação rescisória. ${ }^{55} \mathrm{~A}$ coisa julgada material, por sua vez, é efeito que torna a sentença imutável, que somente se realiza com o julgamento integral do processo, com seu termo e extinção (arts. 203, $\mathbb{S} 1^{\circ}, 204,485$ e 487 do CPC/2015), com a solução de todas as questões que envolvem a lide (arts. 502 e 503 do CPC/2015). ${ }^{56}$ Assim sendo, ainda que

54 A finalidade do processo é a justa composição do litígio. (SOARES, Luso. A responsabilidade processual civil. Coimbra: Almedina, 1987. p. 109). Todavia, "não devemos acreditar que o fim do processo pode não ser alcançado, mas sim acreditar que não pode ser alcançado nunca. Existem equivocações macroscópicas e equivocações microscópicas; isto sim, mas juízos verdadeiros cem por cento são não tanto improváveis quanto impossíveis (...) porém, mesmo que, não tanto pode alcançar a verdade quanto não a pode alcançar nunca até o fundo, o fato [a coisa julgada material] serve, se não precisamente para colocar ordem entre os contendores, ao menos para frear a desordem". (CARNELUTTI, Francesco. Teoria geral do direito. Tradução de Antonio Carlos Ferreira. São Paulo: Lejus, 1999. p. 288).

55 "É certo que o trânsito em julgado decorre da irrecorribilidade; que na hipótese de não conhecimento de um recurso, a decisão recorrida transitou em julgado na própria ocasião em que se configurou a causa da inadmissibilidade. Mas não é a partir desse momento em que se inicia a contagem do prazo para a propositura da ação rescisória, porque 'nenhum prazo pode ter curso quando é impossível sua utilização'. É o princípio da 'utilidade', indissociável da configuração de qualquer prazo, e requer: lapso de tempo para recorrer e possibilidade prática de realização desse ato no curso de sua duração - duração que não pode ser eliminada nem restringida." (CALMON DE PASSOS, José Joaquim. Comentários ao Código de Processo Civil. 8. ed. Rio de Janeiro: Forense, 1998. v. III. p. 167). Na mesma esteira: “a data do trânsito em julgado da decisão de mérito nada tem a ver com a do termo inicial do prazo de decadência para a propositura da ação rescisória. Se esta só cabe quando formada a coisa julgada material, o que ocorre quando esgotado o último recurso, daí decorrerá o prazo preclusivo (decadencial de acordo com a doutrina predominante), que só flui quando pode ser utilizado”. (COSTA, Carlos Coqueijo Torreão da. Ação rescisória. 6. ed. rev. e atualizada por Roberto Rosas. São Paulo: LTr, 2001. p. 127).

56 Dessa forma, o STJ se orienta no sentido de que "o prazo decadencial da ação rescisória tem início no primeiro dia após o trânsito em julgado da última decisão proferida no processo, salvo se se provar que o recurso foi interposto por má-fé do recorrente"; isso porque, continua o voto condutor, uma interpretação adequada "não é absolutamente aquela que se subordina servilmente às palavras da lei, ou que usa de raciocínios artificiais para enquadrar friamente os fatos em conceitos prefixados, mas aquela que se preocupa com a solução justa. Interpretar, já constava das institutas (Geottlieb Heineccio, $\mathbb{2} 28$ ), não é conhecer ou saber as palavras da lei, mas sim a sua força e o seu alcance. A lei, prelecionava o grande Amilcar de Castro, embora nunca ao arrepio do sistema jurídico, deve ser interpretada em termos hábeis e úteis. Com os olhos voltados, aduza-se com Recasens Siches, para lógica do razoável. Como já assinalei em outra oportunidade (cf. RTJ 114/363, no relatório do RE 103/909), o magistrado 
visualizado que um dos capítulos da sentença seja absolutamente imutável durante o curso do processo, é de se reconhecer que o prazo para o ajuizamento rescisório sobre essa questão restará suspenso, uma vez que a ação rescisória pressupõe o encerramento do processo. ${ }^{57-58}$

Perceba-se que a admissão de ação rescisória sem a finalização do processo seria privilegiar o caos, sem contar a possibilidade de novos ajuizamentos com ataque voltados para outros capítulos, proliferando-se ações rescisórias de um mesmo processo.

Note-se que não é possível, na lógica aplicada ao sistema processual brasileiro, via de regra, trabalhar com a ideia de um benefício exagerado de um prazo para ação rescisória alongado para um capítulo que restou definitivamente julgado antes de outro (ex.: exclusão de um litisconsorte pelo pagamento no caso que

não é amanuense da lei, com mera função de conferir fatos com dispositivos legais, aplicando textos com a insensibilidade das máquinas". (REsp 62.353/RJ, Rel. Ministro Sálvio de Figueiredo Teixeira, Quarta Turma, julgado em 26.08.1997, DJ 29.09.1997. p. 48210). Na mesma linha: "o termo inicial para a contagem do prazo do artigo 495 do CPC deve ser o do trânsito em julgado da última decisão da causa, momento em que ocorre a coisa julgada material”. (AR n. 846, Rel. Franciulli Netto, DJU de 01.08.2000). E também o Supremo Tribunal Federal: "é de se considerar que tem início a contagem do prazo, para a propositura da ação rescisória, no momento em que já não cabe qualquer recurso da decisão rescindenda, por não ter sido exercitado, ou por não ser mais exercitável (STF - Pleno: RTJ 120/958, a citação é do voto do Ministro Djaci Falcão)”. (NEGRÃO, Theotonio; GOUVÊA, José Roberto Ferreira. Código de Processo Civil e legislação processual em vigor, nota 5 ao art. 495. 35. ed. São Paulo: Saraiva, 2003. p. 523). Corresponde ao art. 495 do CPC/1973 o art. 975 do $\mathrm{CPC} / 2015$.

57 “O biênio para a propositura da ação rescisória corre da passagem in albis do prazo para recorrer da decisão proferida no julgamento do último recurso interposto no processo, ainda que dele não se tenha conhecido." Em outro passo, perlustra o douto Ministro "que não faz sentido exigir daqueles que interpõem recursos, que - por medida de segurança - ajuízem concomitantemente ações rescisórias contra decisões recorridas, sob pena de - aí sim - inviabilizarmos o Judiciário”. (STJ - REsp 11.106/SC, Rel. Ministro Adhemar Maciel, DJ 10.11.1997).

58 Convém ressaltar que há doutrinas que entendem de maneira diversa: "Resumindo, em geral, o termo a quo do prazo para se propor ação rescisória é a data em que transitar em julgado cada um dos capítulos de sentença, pois o art. 975, caput, CPC/2015, estabelece apenas o termo ad quem do prazo decadencial de ação rescisória, jamais impedindo o ajuizamento da ação antes do trânsito em julgado da última decisão proferida no processo (sobre o tema: Ravi Peixoto, Ação rescisória e capítulos de sentença: a análise de uma relação conturbada a partir do CPC/2015, Doutrina selecionada - Processos nos tribunais e meios de impugnação às decisões judiciais, Salvador, JusPodvim, 2015, v. 6, no prelo (...)”. (ALVIM, Angélica Arruda (coord.) [et al.]. Comentários ao Código de Processo Civil, p. 1125). 
este era demandado apenas por prejuízos específicos), que, por sua vez, teria o prazo de início da ação rescisória contado imediatamente do trânsito em julgado material, porquanto a solução teria sido resolvida definitivamente somente na última decisão do processo. ${ }^{59}$

59 Nesse sentido, "continuo lendo a lei, como aprendi com Aliomar Baleeiro e Orlando Gomes, alinhados com Kelsen, e volto a dizer que sentença é uma só. A sentença é o ato que põe termo ao processo art. $162, \mathbb{S} 1^{\circ}$, do CPC, vale dizer, extingue o processo (art. 269, I, CPC). No art. 269 , inciso I, está dito que se extingue o processo com julgamento de mérito quando o juiz acolher ou rejeitar o pedido do autor. Não há, no processo brasileiro, coisa julgada material de capítulos de sentença. Aliás, não se diga que Pontes de Miranda fez tal afirmação, porque o ilustre jurista definiu com precisão coisa julgada formal e coisa julgada material. A coisa julgada em meio ao processo, a chamada coisa julgada formal, que, na verdade, é preclusão (art. 473/CPC), não constitui coisa julgada material, e nem poderia, porque o processo é um caminhar para a frente, e não se pode imaginar que a parte irrecorrida da sentença pudesse constituir coisa julgada oponível às partes. Não é essa a coisa julgada consagrada na Constituição ou na Lei de Introdução e no CPC. Coisa julgada material é a sentença de que não cabe mais recurso, e sentença é ato que põe termo ao processo (art. 162, $\mathbb{S} 1^{\circ}$ do CPC). O prazo para a ação rescisória conta-se do trânsito em julgado da sentença. No CPC, talvez por vezo de não se repetir expressão, diz-se decisão, e, neste caso, cogita-se de sentença transitada em capítulos. Mas é Barbosa Moreira que, interpretando Pontes de Miranda, defende o trânsito em julgado de parte da sentença, quem diz da sinonímia jurídica entre sentença 'rescindenda' e 'decisão', como diz o CPC no art. 495. É ver a nota 314 nos Com. ao CPC, art. 495 do renomado processualista, pág. 250, 4. ed. Forense. Em outro artigo, diz o art. 463 que o juiz não pode modificar decisão, e que constitui coisa julgada a sentença indiscutível, não mais sujeita a recursos (art. 467/CPC). Ora, como contar o prazo para a ação rescisória? Como se admitir ações rescisórias em julgados no mesmo processo? É impossível conceber-se a existência de uma ação em curso, ou seja, a pretensão submetida ao julgamento do Estado e, no seu curso, enquanto a ação existir, várias ações rescisórias no seu bojo, como bem assinalou o eminente Ministro Franciulli Netto. Se isso é posto dentro da realidade brasileira de morosidade excessiva do Judiciário por força mesmo desse processo, que não acaba nunca, vai-se ao absurdo de imaginar que seja possível, por exemplo, a parte perder o prazo da rescisória, porque houve retardamento na decisão do seu recurso especial ou do seu recurso extraordinário. Lembrou, aliás, muito bem, o Sr. Ministro Humberto Gomes de Barros, que, se a parte for açodada e propuser a ação rescisória de imediato, e se afirmar que não é da decisão incidental, e, sim, da última, quem pagará os honorários? Como se admitir que haja coisa julgada material oponível, ou seja, sentença valendo lei, enquanto em curso o processo? Como se admitir, volto a dizer, que ações rescisórias sejam postas contra 'capítulos' à sentença, que não põe termo ao processo? Parece-me volto a dizer que continuo convencido e que insisto, em prol, quem sabe, de fazer com que se discuta, ao menos dentro da lei e nos termos que ela põe -, em respeito à unicidade da sentença, porque sentença é una, não se divide, não pode ser fracionada para efeito da ação rescisória, que não se pode admitir ataque à parte de sentença irrecorrida, enquanto em curso o processo". In: voto mérito da lavra do Sr. Ministro Francisco Peçanha Martins, do STJ, nos Embargos de 
Portanto, em uma primeira conclusão destas linhas, conquanto se possa pensar em exceções $(v \cdot g$., possibilidade de solução definitiva de um dos pedidos que diga respeito a somente um dos litisconsortes, redundando em sua exclusão do polo initio litis, não pela ilegitimidade, mas por acordo nos autos ou pelo pagamento em ação de cobrança), devendo o julgador atentar para casos particulares de início diferenciado do prazo decadencial da ação rescisória, a regra geral será a contagem única, da última decisão proferida no processo, devendo ser extinta a ação rescisória proposta prematuramente, ante a falta de pressuposto específico, qual seja, o trânsito em julgado material da sentença de mérito. ${ }^{60}$

Prosseguindo-se, em aprofundamento do tema, de fato, ante a possibilidade de haver decisões por capítulos com reflexos diretos no prazo para propositura da ação rescisória, releva concluir que tais questões devem ser analisadas caso a caso.

Em suma, como regra geral, para quem tomou parte do último e derradeiro recurso no processo, o prazo da ação rescisória conta-se do trânsito em julgado da decisão deste. Nesse caso, vale a lição de que a formação da coisa julgada envolve a sentença lato sensu, composta por todas as decisões produzidas e vigentes ao tempo da última decisão no processo, seja de mérito ou não. ${ }^{61}$ Mas isso corre somente para as partes que estão no processo, porque a sentença, via de regra, não pode vincular quem não seja ou não esteja como parte.

Divergência em REsp 404.777/DF (2003/0125495-8), DJU 11.04.2005. Correspondem aos arts. 162, 269, 463, 473 e 495 do CPC/1973, respectivamente, os arts. 203, 487, 494, 507 e 975 do CPC/2015.

${ }^{60}$ No caso, inclusive, será impossível preencher o requisito da juntada, com a inicial rescisória, da certidão do trânsito em julgado, para comprovar a rescindibilidade e a tempestividade. Invariavelmente, uma leitura atenta dos autos redundará na instrução deficiente desta demanda, afastando o enquadramento nos termos do disposto no art. 485, em um de seus incisos, do CPC, razão pela qual, não se poderá dar prosseguimento ao feito rescisório. O indeferimento da inicial e a extinção do processo rescisório serão de rigor nos casos da espécie - notadamente com base nos arts. 267, inciso I, 295, inciso III e 490, inciso I, do Código de Processo Civil. Nesse sentido, é a seguinte ementa: "Ação Rescisória. Inicial indeferida. Ausência do trânsito em julgado. Extinção do feito”. (TJSP - Ação Rescisória 0543008-24.2010.8.26.0000, 6ª Câmara de Direito Privado, Rel. José Joaquim dos Santos, julgado em 10.02.2011, public. 22.02.2011). Correspondem aos arts. 267, 295, 485 e 490 do CPC/1973, respectivamente, os arts. 485, 330, 966 e $968, \mathbb{S} 3^{\circ}$, do CPC/2015.

61 “O termo 'a quo' para o ajuizamento da ação rescisória coincide com a data do trânsito em julgado da decisão rescindenda. O trânsito em julgado, por sua vez, se dá no dia imediatamente subsequente ao último dia do prazo para o recurso em tese cabível”. (STJ - REsp 1112864 MG 2009/0059035-4, Rel. Ministra Laurita Vaz, julgado em 19.11.2014, CE - Corte Especial, DJe 17.12.2014). 
Nessa esteira, visando a uma solução para a excepcionalidade da pluralidade de parte, tendo finalizado o processo prematuramente para uma, com decisão de mérito, então, para esta restará formada a coisa julgada material até onde tenha ela atuado ou deveria atuar, em função dos efeitos de eventual revelia. Nessa situação, a ação rescisória será admitida desde logo, não importando que a lide remanescente continue pendente de julgamento. ${ }^{62}$

Frise-se que o recurso ordinário ou extraordinário, desde que ataque a decisão com partes subjetivamente autônomas, não impede o trânsito em julgado do capítulo do decisum que não foi impugnado, e, nesse caso, conta-se de imediato o prazo decadencial para a propositura da ação rescisória por um dos réus ou pelo autor; quanto a este, versando sobre o tema não recorrido, uma vez que se trata de ação com pluralidade de lides no aspecto subjetivo facultativo. ${ }^{63}$

A título ilustrativo, avente-se um caso de acidente de trânsito em que o veículo do autor tenha sido atingindo por outro e, nada sofrendo fisicamente, quando desceu para averiguar o estrago, acabou sendo atingido por terceiro veículo, fraturando os membros inferiores. Em face dos desígnios autônomos, os prejuízos são separáveis e indenizáveis separadamente. Proposta uma ação em face dos condutores dos dois veículos, o pedido de reparação de danos materiais no veículo se direciona contra o primeiro réu, e os pedidos de danos estéticos, indenização hospitalar e lucros cessantes se direcionam contra o segundo réu. Sendo o primeiro réu revel, a sentença definitiva condenatória foi proferida de imediato e autorizada a execução da sentença no pedido referente aos danos materiais no veículo. A ação continua contra o outro réu; está na fase de provas. Então não haverá motivos para que seja extinta a ação rescisória proposta pelo primeiro réu, se preencher uma das hipóteses de cabimento do art. 966 do CPC/2015, mesmo que

62 "A relação processual principia com o ingresso da ação (a citação é exigência para fluir o tempo para resposta) e termina quando expira o prazo para recorrer da última decisão. Daí surge o fenômeno da coisa julgada (muitas vezes, sem precisão técnica, confundida com a preclusão). Para efeito de correr o prazo para propor ação rescisória, o termo a quo é contado do dia seguinte ao término do prazo do recurso adequado para atacar a decisão, ou de seu julgamento se interposto." (STJ-REsp 41.488/RJ, Rel. Ministro Luiz Vicente Cernicchiaro, DJ 28.03.1994).

${ }^{63}$ O Superior Tribunal de Justiça já pacificou o entendimento de que "se partes distintas da sentença transitaram em julgado em momentos também distintos, a cada qual corresponderá um prazo decadencial com seu próprio dies a quo, para fins de ajuizamento de ação rescisória: vide PONTES DE MIRANDA. Tratado da ação rescisória, 5. ed., p. 353. (in Comentários ao Código de Processo Civil, de José Carlos Barbosa Moreira, v. V, Editora Forense, 7. ed., 1998, p. 215, nota de rodapé n. 224). Precedente: REsp 212.286/RS, Rel. Ministro Hamilton Carvalhido, DJ 29.10.2001.” (STJ - REsp 363.568/RS, Rel. Ministro José Arnaldo da Fonseca, $5^{\text {a }}$ Turma, julgado em 24.09.2002, DJ 04.11.2002. p. 230). 
a ação originária esteja em curso contra o outro réu. ${ }^{64} \mathrm{~A}$ lide em curso não lhe diz respeito, então o trânsito em julgado material já se terá operado para o primeiro réu, e não para o segundo. O fato de haver a cumulação subjetiva facultativa da ação não pode mudar a realidade das coisas.

O que justifica o critério do último recurso é a possibilidade de mudança no julgamento, inclusive pelo conhecimento de matéria de ordem pública. Assim, "dentro de um conflito de interesses pode ser instaurada uma ou várias lides. A composição, uma vez resistida a pretensão, poder-se-á dar num ou em vários processos. Escolhido pela parte autora um único processo para resolver sua lide ou suas lides, a composição final há de ocorrer por meio de uma única sentença, visto que a sentença deve ser certa e se conter nos limites do pedido, porque, se assim não for, será nula, ou anulável, por extra, citra ou ultra petita." ${ }^{65}$ Mas o princípio da unicidade da sentença está vinculado à existência do processo para as partes. ${ }^{66}$

Portanto, a solução é a mesma que se obteria se as ações fossem propostas em separado, mas essa regra não vale para pedidos diversos direcionados à mesma parte, porque vige a regra da unidade da sentença (v.g., decisão de mérito) para o mesmo processo. ${ }^{67}$

64 "Pressuposto básico para o ajuizamento da ação rescisória, respeitado o prazo bienal de decadência - Código de Processo Civil, art. 495 -, é a existência de uma sentença, ou acórdão, que haja transitado em julgado, adquirindo a imutabilidade inerente à coisa julgada material.” (CARNEIRO, Athos Gusmão. Ação rescisória, biênio decadencial e recurso parcial. Doutrinas Essenciais de Processo Civil, São Paulo: RT, v. 7, out. 2011. p. 1321). Corresponde ao art. 495 do CPC/1973 o art. 975 do CPC/2015.

${ }^{65}$ Voto nos Embargos de Divergência em REsp 404.777/DF (2003/0125495-8), da lavra do Exmo. Sr. Ministro Franciulli Netto, DJU 11.04.2005.

66 "Para evitar dúvida interpretativa no sistema recursal, a redação do NCPC não mais fala em resolução do processo. Para o Novo Código, sentença é o pronunciamento judicial, recorrível por apelação (art. 1.009), cujo efeito principal é estabelecer o encerramento da fase cognitiva do procedimento comum ou de extinguir a execução”. (ALVIM, Angélica Arruda (coord.) [et al.]. Comentários ao Código de Processo Civil, p. 282).

${ }^{67}$ No processo civil italiano, a solução da lide pode ser fracionada (articolo 324 do Codice di Procedura Civile) e no direito brasileiro, não. "No primeiro, o mérito pode ser objeto de mais de uma sentença (por exemplo quando o juiz rejeita uma exceção); no segundo o mérito é totalmente decidido em uma única sentença. Apenas em casos excepcionais, como na rejeição da prescrição, é que no processo civil pátrio admite-se solução fracionada do mérito. Quanto às sentenças que decidem uma questão preliminar de mérito, sem julgar toda a lide, mais tarde viriam a ser denominadas de 'sentenças endoprocessuais' por Montesano, no sentido de que os seus efeitos são circunscritos ao processo.” (FERREIRA FILHO, Manoel Carlos. A preclusão 
Explica-se: para o segundo réu, o trânsito em julgado formal de um dos pedidos não interferirá no trânsito em julgado material, que só ocorrerá quando for proferida a última decisão no processo, seja de mérito ou não. Assim restará preservado o princípio da unidade da sentença, porque não se trata propriamente de capítulo da sentença, e sim de formação de uma sentença una e indivisível, vinculativa entre as partes, sendo que a coisa julgada formada mais à frente não dirá respeito à parte prematuramente excluída e ao respectivo autor. ${ }^{68}$ Embora reunidos no mesmo procedimento pela cumulação subjetiva facultativa, participam nitidamente de processos distintos. O processo de conhecimento é o procedimento em contraditório, ${ }^{69-70} \mathrm{e}$, no caso aventado, já não haverá mais processo de conhecimento entre o autor e o réu, eis que este já estará condenado definitivamente, por sentença transitada em julgado, porque não haverá mais possibilidade de contraditório, uma vez extinta a relação processual.

Saliente-se que não estamos aqui a falar da decisão que habilite a execução provisória, que tem outro regramento, sendo permitida antes do trânsito em julgado, antes da decisão de mérito definitiva. Assim, excetua-se dessa regra o caso

no direito processual civil. Curitiba: Juruá, 1991. p. 69). Vide também: MONTESANO, Luigi. Cinquant'anni del codice civile (I). Collana: Università degli Studi di Milano - Facoltà di Giurisprudenza. Milano: Giuffrè, 1993. p. 82 e ss.

${ }^{68}$ Portanto, "se a prestação principal do juiz pode cumprir-se por etapa (in più volte), como no caso de cumulação de pedidos, qualquer sentença que decide sobre um dos pedidos, ou sobre uma parte do pedido é definitiva se bem que parcial (...) Contra essas decisões cabe evidentemente ação rescisória”. (VIDIGAL, Luis Eulálio de Bueno. Comentários ao Código de Processo Civil. 2. ed. São Paulo: RT, 1976. v. VI. p. 47).

$69 \mathrm{Na}$ concepção da contemporânea configuração da relação jurídica, "processo é o procedimento em contraditório". (FAZZALARI, Elio. Istituzioni di diritto processuale. Padova: Cedam, 1994. p. 85$)$.

70 “O CPC evidencia a sua preocupação com o contraditório ao estabelecer, no art. $9^{\circ}$, que: 'Não se proferirá decisão contra uma das partes sem que esta seja previamente ouvida', excepcionando-se as hipóteses de tutela provisória de urgência, de tutela de evidência prevista no art. 311, incisos I e II, e a decisão prevista no art. 701, isto é, de expedição de mandado de pagamento, de entrega de coisa ou execução de obrigação de fazer ou não fazer, quando preenchidos os requisitos para o processamento da ação monitória. Além disso, com o intuito de evitar que qualquer dos litigantes seja surpreendido por decisão judicial sem que tenha tido oportunidade de se manifestar, prescreve o art. 10 que: 'O juiz não pode decidir, em grau algum de jurisdição, com base em fundamento a respeito do qual não se tenha dado às partes oportunidade de se manifestar, ainda que se trate de matéria sobre a qual deva decidir de ofício'. Veda-se assim a decisão-surpresa, em que o juiz se vale de fundamento cognoscível de ofício, que não havia sido anteriormente suscitado, sem dar às partes oportunidade de manifestação". (GONÇALVES, Marcus Vinicius Rios. Direito processual esquematizado, p. 66-67). 
em que o juiz antecipar a tutela com base no art. 311 do CPC/2015, pois, embora seja solução que se amolde ao mesmo caso proposto, o julgador terá proferido tutela antecipada a ser confirmada na sentença, e não sentença definitiva. O tema da tutela antecipada deverá figurar na sentença definitiva, para confirmá-la ou para revogá-la, mesmo que proferida com base no dito dispositivo.

No caso em que houver decisão de mérito condenatória, por exemplo, em dano moral e dano material, bem como em honorários advocatícios, uma vez interposto recurso apenas contra a fixação de honorários advocatícios, haveria então a possibilidade de execução definitiva de parte da sentença em que foi reconhecido o direito indenizatório, pois o pressuposto da execução provisória é a existência de recurso sem efeito suspensivo (art. 520 do CPC/2015); ${ }^{71}$ afastada essa hipótese, a execução se processa de modo definitivo. ${ }^{72}$

Inequivocamente, nessa hipótese, haverá o trânsito em julgado formal de parcela da decisão de mérito, para efeitos da execução definitiva da condenação por dano moral e material; porém não se abrirá o prazo para a ação rescisória, uma vez que somente fluirá a partir do julgamento de todos os recursos, com o trânsito em julgado material, que ocorre somente da última decisão proferida nos autos, determinando-se o fim do processo como um todo. É a aplicação do princípio da unidade da sentença.

71 "A execução provisória é a possibilidade que o ordenamento jurídico dá àquele que queira iniciar os atos expropriatórios quando ainda pendente de julgamento algum recurso interposto que não tenha sido atribuído efeito suspensivo, de acordo com os artigos 520 e $1.012, \mathbb{S} \mathbb{S} 1^{\circ} \mathrm{e}$ $2^{\circ}$, do NCPC. Inexiste, pois, na execução/cumprimento provisório da sentença, o trânsito em julgado da decisão que se queira executar. Justamente por este fato, pode haver mudança no título provisório que se está estudando, que se está dando cumprimento, motivo pelo qual corre por conta e risco do exequente, 'que se obriga, se a sentença for reformada, a reparar os danos que o executado haja sofrido’ (NCPC, art. 520, I).” (OLIVEIRA, Weber Luiz de. Execução da parte incontroversa no Novo Código de Processo Civil. In: DIDIER JR., Fredie (coord.); MACÊDO, Lucas Buril de; PEIXOTO, Ravi; FREIRE, Alexandre. Novo CPC - doutrina selecionada, v. 5: execução. Salvador: JusPodivm, 2016. p. 405).

$72 \mathrm{O}$ recurso recebido com efeito suspensivo não enseja nenhuma execução, nem provisória nem definitiva, pois, como o próprio nome já sugere, há suspensão do processo para julgamento do recurso, salvo execução provisória. "A Lei 11.232/2005 mantém a posição de que é definitiva a execução da sentença transitada em julgado e provisória quando se tratar de sentença impugnada mediante recurso ao qual não foi atribuído efeito suspensivo. Iniciada a execução provisória da sentença, o não pagamento do débito no prazo de quinze dias ensejará a aplicação de multa de $10 \%$ sobre o débito. Contudo, o provimento do recurso, com a consequente reversão do julgado, torna inexigível a multa anteriormente aplicada.” (BARIONI, Rodrigo Otávio. Cumprimento da sentença. Revista de Processo 134/53, São Paulo: RT, abr. 2006; Doutrinas Essenciais de Processo Civil, v. 8, out. 2011 e Revista de Processo, RePro 134/53, abr. 2006). 
É por isso que se afirmou que a sentença stricto sensu e seus capítulos, se considerados isoladamente, em regra, não terão efeito para a contagem do prazo rescisório, a menos que se trate de quem não seja mais parte ao tempo da última decisão, razão pela qual, para este, o trânsito em julgado já se terá operado em decisão anterior ou, se a sua exclusão se deu por decisão terminativa, então esta decisão não será alcançada pela coisa julgada material, mas poderá ser rescindida se impedir o ajuizamento da mesma demanda ou se houver o não conhecimento, indevido, do recurso interposto contra tal decisum, nos termos do art. $966, \mathbb{S} 2^{\circ}$, incs. I e II, do CPC/2015. .3-74 $^{-1}$

O Superior Tribunal de Justiça pacificou o entendimento pelo cabimento da ação rescisória ao final, com o derradeiro trânsito em julgado, não admitindo a ação rescisória para enfrentar os chamados capítulos da sentença - Súmula 401. ${ }^{75}$

Em oposição a esse pensamento, é veemente a crítica doutrinária, ${ }^{76} \mathrm{em}$ especial porque a alteração da definição de sentença contida no art. $162, \mathbb{S} 1^{\circ}$, do CPC/1973,77 com redação dada pela Lei n. 11.232, de 2005, com significado

73 "Quando há pluralidade de partes, caracterizada pelo litisconsórcio ou certas modalidades de intervenção de terceiros, o 'trânsito em julgado para uma das partes' significa que o capítulo que diz respeito a ela já passou em julgado, não porém os que dizem respeito aos outros litigantes." (DINAMARCO, Cândido Rangel. Capítulos da sentença, 2002, p. 119).

74 "A decisão que equivocadamente reconhece a existência de litispendência ou de coisa julgada, por exemplo, não constitui decisão de mérito, mas impede a sua discussão em processo posterior. Se determinado recurso é inadmitido, isto é, não conhecido, de forma equivocada, cabe ação rescisória para desconstruir a decisão que não o conheceu, posto que não se trate de decisão de mérito. Isso porque, nesse caso, o não conhecimento equivocado do recurso impede a rediscussão do mérito da causa - imaginando-se que o recurso inadmitido atacou decisão de mérito - ou mesmo a sua discussão - imaginando-se que o recurso inadmitido não atacou decisão de mérito. Em qualquer desses casos, há decisão impeditiva, cujo óbice pode ser removido mediante a propositura de ação rescisória”. (MARINONI, Luiz Guilherme; ARENHART, Sérgio Cruz; MITIDIERO, Daniel. Novo Código de Processo Civil comentado, p. 1021).

75 Súmula 401, STJ: “O prazo decadencial da ação rescisória só se inicia quando não for cabível qualquer recurso do último pronunciamento judicial".

76 "Se partes distintas da sentença transitaram em julgado em momentos também distintos, a cada qual corresponderá um prazo decadencial com seu próprio dies a quo: vide Pontes de Miranda, Tratado da ação rescisória. 5. ed., p. 353.” (MOREIRA, José Carlos Barbosa. Comentários ao Código de Processo Civil. 7. ed. Rio de Janeiro: Forense, 1998. v. 5. p. 215).

77 "Sempre nos pareceu, portanto, ser esta a nota marcante das sentenças, ou seja, é o seu conteúdo, preestabelecido por lei de forma expressa e taxativa, que as distingue dos demais pronunciamentos do juiz." (WAMBIER, Teresa Arruda Alvim. Nulidades do processo e da sentença, 6. ed., 2007, n. 16, p. 33). 
similar mantido no art. 203, $\mathbb{S} 1^{\circ}$, do CPC/2015, no que diz respeito ao conteúdo que uma sentença deve apresentar (apenas acrescentando que esta põe fim ao processo de conhecimento ou execução), ${ }^{78}$ daria azo à conclusão diversa daquela emanada pelo STJ. ${ }^{79}$

Todavia, atuando no sentido de conferir interpretação mais branda e mais favorável ao autor da ação rescisória, o STJ acabou por demonstrar grande sensibilidade e respeito ao jurisdicionado, fazendo justiça com extrema simplicidade. $\mathrm{Na}$ verdade, não há prejuízo maior a qualquer das partes; ao contrário, adota-se posição mais garantista.

Com isso, o STJ deixa claro que os novos tempos não são de um tecnicismo processual exagerado, mas de simplificação de regras em benefício e proteção da própria efetividade da jurisdição.

Esse é o maior crédito que a justiça pode outorgar na interpretação autêntica da lei: a previsibilidade e, por meio dela, a própria segurança jurídica. ${ }^{80}$

De qualquer sorte, a coisa julgada material, ou substancial, só há de ocorrer com a resolução da lide e a extinção completa do processo. Aí se inclui o respeito à formação do processo, com sua atuação subjetiva em contraditório. Portanto, a coisa julgada material não pode ser outra senão a qualidade conferida por lei à sentença lato sensu, aquela que se atinge quando, reunidos todos os seus capítulos,

78 “O CPC atual, embora mantendo a alusão ao conteúdo do pronunciamento judicial, que deve estar fundado nos arts. 485 e 487 (quando não há ou há resolução de mérito, respectivamente), torna a definir a sentença por sua aptidão de pôr fim ou ao processo ou à fase de conhecimento em primeiro grau de jurisdição”. (GONÇALVES, Marcus Vinicius Rios. Direito processual esquematizado. 525).

79 Nos ensinamentos doutrinários colhe-se também: "note-se desde já que o argumento, assim formulado, leva à conclusão inevitável de que tampouco seria possível tentar rescindir qualquer delas após o encerramento do processo. Não se concebe logicamente que este tenha a virtude de converter em coisa julgada material a preclusão ou a coisa julgada formal a que se haja sujeitado alguma sentença anterior. Só da última é que se poderia cogitar aí. Significa isso que, em eventual ação rescisória, apenas seria possível tentar desconstituir a última sentença, assegurada a subsistência de todas as outras pelo fato de não satisfazerem os requisitos do art. 485 do CPC ('A sentença de mérito, transitada em julgado, pode ser rescindida (...)') e não serem, por isso, rescindíveis”. (MOREIRA, José Carlos Barbosa. Sentença objetivamente complexa, trânsito em julgado e rescindibilidade. RePro, São Paulo: RT, v. 141. p. 7-19, nov. 2006. p. 12). Corresponde ao art. 485 do CPC/1973 o art. 966 do CPC/2015.

80 "A decadência do direito de desconstituir, em ação rescisória, a coisa julgada material implementa-se no prazo de dois anos iniciado no dia seguinte ao término do prazo para a interposição do recurso em tese cabível contra o último pronunciamento judicial.” (STJ - AR 4.374/MA, Rel. Ministro Paulo de Tarso Sanseverino, $2^{\text {a }}$ Seção, julgado em 09.05.2012, DJe 05.06.2012). 
possa se dar por encerrada a relação episódica da lide, com as soluções epistemes proferidas pelo Estado-juiz, incumbido de dirimir e extinguir as controvérsias e incertezas em torno da causa de pedir, adotando-se como limite aos pedidos formulados na exordial, de modo a garantir a intangibilidade do resultado do processo, isto é, o reconhecimento ou a negação do bem da vida buscado pelo autor. Isso porque este elegeu a solução da sentença judicial como substituta de sua vontade, possibilitando inserir, o quanto possível, a convivência pacífica das partes em sociedade, sagre-se vencedora ou não na demanda judicial. ${ }^{81}$

\subsection{FALTA DE DILIGÊNCIA DA PARTE E DECADÊNCIA DECRETADA EM AJUIZAMENTO TEMPESTIVO: CITAÇÃO POSTERIOR AO BIÊNIO}

Naturalmente, na ação rescisória proposta, além do prazo legal, será reconhecida a decadência, dada a extemporaneidade, devendo o processo ser extinto com base no art. 487, III, alínea $a$, do CPC/2015.

Todavia, o mero ajuizamento da ação rescisória dentro do prazo não garante o cumprimento da tempestividade. Vale dizer, mesmo após o ajuizamento da ação rescisória, a decadência pode ser declarada.

Desse modo, o autor deve cuidar de realizar um ajuizamento perfeito, o que inclui a juntada, ab initio (ou, ao menos, assim que possível, dentro do prazo judicial fixado para aditamento), de toda a documentação necessária para análise do mérito, visando ao regular processamento do feito rescisório, pois a paralisação do processo, por culpa do autor, resultará na decadência do direito. É que, nessa situação, a contagem do decurso do prazo pode ser complementada pelo transcurso posterior ao ajuizamento. ${ }^{82}$

De outro lado, em sendo tempestiva a distribuição da ação rescisória, a citação posterior à expiração do biênio, por si só, não implicará automaticamente a declaração da decadência, ${ }^{83}$ pois o procedimento comporta a dilação normal do prazo para efeitos citatórios. ${ }^{84}$

81 CHIOVENDA, Giuseppe. Instituições de direito processual civil, 1969, v. 1, p. 382.

${ }^{2}$ STF, Súmula 264: "Verifica-se a prescrição intercorrente pela paralisação da ação rescisória por mais de cinco anos”. (Aprovada em 13.12.1963 - Imprensa Nacional, 1964, p. 122.). A referência legislativa era do Código Civil de 1916, art. 178, $\mathbb{1 0}$, VIII, que vigia antes do CPC de 1973, que veio a alterar o prazo para 2 (dois) anos.

83 STJ, Súmula 106: "Proposta a ação no prazo fixado para o seu exercício, a demora na citação, por motivos inerentes ao mecanismo da Justiça, não justifica o acolhimento da arguição de prescrição ou decadência”. (DJ 03.06.1994).

84 "Ação rescisória. Petição inicial ajuizada no último dia do biênio decadencial, pedindo, antecipadamente, a prorrogação do prazo para a citação. Realização desta dentro da prorrogação. 


\subsection{IMPORTÂNCIA DO PRAZO PARA O ESTUDO DA TUTELA ANTECIPADA}

Por fim, anote-se que o tema da intempestividade da propositura da ação rescisória tem interesse direto para a análise do tema de fundo: a tutela antecipada na ação rescisória. No caso de intempestividade da propositura da ação rescisória, não haverá que se falar em deferimento da tutela antecipada. O requerimento liminar deve ser declarado prejudicado em função do não conhecimento da ação rescisória.

Após o lapso temporal de dois anos, contados do trânsito em julgado na forma da lei, ${ }^{85}$ ocorre a imutabilidade e indiscutibilidade, denominada coisa soberanamente julgada ${ }^{86}$ não se admitindo mais a desconstituição da coisa julgada nem mesmo por meio da ação rescisória.

Decadência não configurada. Precedentes do Supremo Tribunal Federal. Recurso extraordinário conhecido e provido.” (STF - RE 90.240, Rel. Ministro Soares Munhoz, 1ª Turma, julgado em 14.08.1979, DJ 31.08.1979. p. 6470).

85 “O prazo para ajuizar ação rescisória começa a fluir no dia seguinte ao término do prazo do último recurso cabível, quando este é interposto intempestivamente." (AR n. 377/DF, Rel. Ministro Paulo Gallotti, DJU 13.10.2003). "Consoante o disposto no art. 495 do CPC, o direito de propor a ação rescisória se extingue após o decurso de dois anos contados do trânsito em julgado da última decisão proferida na causa”. (EREsp 404.777/DF, Rel. Ministro Francisco Peçanha Martins, DJU 11.04.2005). "O prazo decadencial da ação rescisória conta-se do trânsito em julgado da decisão rescindenda, que se aperfeiçoa ou com o exaurimento dos recursos cabíveis ou com o decurso, in albis, dos prazos para sua interposição pelas partes - ratio essendi do art. 495, do CPC”. (STJ - REsp 639.233/DF, $1^{\text {a }}$ Turma, Rel. Ministro José Delgado, DJ 14.09.2006). Corresponde ao art. 495 do CPC/1973 o art. 975 do CPC/2015.

86 "Seu objeto - os pronunciamentos judiciais rescindíveis - equiparam-se, segundo lição de Teresa Arruda Alvim Wambier, aos atos anuláveis, vez que, em regra, salvo na hipótese de ausência ou vício de citação do demandado (art. 475-L, $\mathbb{S} 1^{\circ}$, e $741, \mathrm{I}, \mathrm{CPC}$ ) passado o prazo bienal de seu ajuizamento, os vícios se tornam imutáveis, fazendo-se presente a coisa soberanamente julgada”. (FARIA, Márcio Carvalho. Considerações sobre o prazo rescisório no Novo CPC. In: DIDIER JR., Fredie (coord.); MACÊDO, Lucas Buril; PEIXOTO, Ravi; FREIRE, Alexandre. Novo CPC - doutrina selecionada, v. 6: processo nos tribunais e meios de impugnação às decisões judiciais, p. 199). 
